\section{Transforming landscapes: Modeling land-use patterns of environmental borderlands}

2019, Vol. 29(10) 1572-1586

(C) The Author(s) 2019 (c) (1) (9)

Article reuse guidelines: sagepub.com/journals-permissions DOI: $10.1177 / 0959683619857233$ journals.sagepub.com/home/hol

@SAGE

\author{
Daniel Knitter,' (D) Jan Piet Brozio,2 (D) Walter Dörfler, ${ }^{2}$ \\ Rainer Duttmann,' Ingo Feeser, ${ }^{2}$ (D) Wolfgang Hamer,' \\ Wiebke Kirleis, ${ }^{2}$ Johannes Müller' (D) and Oliver Nakoinz ${ }^{2}$
}

\begin{abstract}
How did socio-cultural transformation processes change land-use patterns? Throughout the last 50 years, outstanding comprehensive geographic, archaeobiological, and archaeological data have been produced for the area of Oldenburger Graben, Schleswig-Holstein, Germany. Based on this exceptional data set, we are able to study the land-use patterns for a period ranging from the Final Mesolithic until the Late Neolithic (4600-I700 BCE). By application of fuzzy modeling techniques, these patterns are investigated diachronically in order to assess the scale of transformations between the different archaeological phases. Based on nutrient requirements and proposed dietary composition estimates derived from empirical archaeobotanical, archaeozoological, and stable isotope data, the required extent of the areas for different land-use practices are modeled. This information is made spatially explicit using a fuzzy model that reconstructs areas of potential vegetation and land-use for each transformation phase. Pollen data are used to validate the type and extent of land-use categories. The model results are used to test hypotheses on the dynamics of socio-cultural transformations: can we observe a diversification of land-use patterns over time or does continuity of land-use practices prevail? By integrating the different lines of evidence within a spatially explicit modeling approach, we reach a new quality of data analysis with a high degree of contextualization. This allows testing of hypotheses about Neolithic transformation processes by an explicit adjustment of our model assumptions, variables, and parameters.
\end{abstract}

\title{
Keywords
}

fuzzy logic, landscape archaeology, land-use quantification, neolithization, social dynamics, vegetation reconstruction

Received 9 December 2018; revised manuscript accepted 26 March 2019

\section{Introduction}

The aim of this paper is to gain a deeper understanding of the interaction between humans and the environment during the Neolithic in North-Central Europe. The study focuses on settlements of the Late Mesolithic and Neolithic periods between 4600 and 1700 BCE in a former firth region of the Oldenburg Graben, at the Western Baltic Sea, Germany. The time span considered includes a variety of cultural-historical phenomena such as (a) the partly residential forager societies of the last phase of the Late Ertebölle Mesolithic (Hartz et al., 2007; Sørensen et al., 2018); (b) the mainly residential Funnel Beaker groups (Brozio, 2016; Müller, 2012); (c) potentially more mobile Single Grave Culture societies (Brozio, in press; Schultrich, 2018), as the northern appearance of the Corded Ware phenomenon; and (d) the dagger period groups at the end of the Neolithic (Kühn, 1979; Schwarck, 2018; Vandkilde, 1996). ${ }^{1}$ While manifold transformations of the societies are mirrored in changing cultural remains, the impact of these mostly sedentary groups on their environment is still a matter of discussion. By modeling the spatial extent of landuse activities, we aim to assess whether the land-use intensity was so strong that in certain phases the carrying capacity of the natural environment was reached and might therefore be another reason for the occurrence of socio-cultural transformations.

Within our study area, the archaeological documentation, prospection, and excavation activities are among the greatest on a European scale. Thus, the evaluation of components of the subsistence economy based on a comprehensive settlement sample is possible. Based upon estimations regarding settlement sizes and diet, we quantify and map the potential land-use of Neolithic societal groups in order to illustrate how the cultural-historical transformations manifest themselves spatially. The results are compared and validated with pollen data from an off-site archive.

Our approach focuses on transformations phases, which we define as periods where discontinuities and innovations appear in a way that sustainable changes are visible in the archaeological or paleoecological record.

\section{Environmental characteristics of the study area}

The research area is part of the Eastern Uplands (Östliches Hügelland; Fränzle, 2004), an area that was formed by moraines of the Weichselian Glaciation. The highest elevation is the Bungsberg

\footnotetext{
'Department of Geography, Physical Geography, Christian-AlbrechtsUniversität zu Kiel, Germany

${ }^{2}$ Institute of Pre- and Protohistoric Archaeology, Christian-AlbrechtsUniversität zu Kiel, Germany
}

\section{Corresponding author:}

Daniel Knitter, Department of Geography, Physical Geography, Christian-Albrechts-Universität zu Kiel, Ludewig-Meyn-Str. 14, 24I I8 Kiel, Germany. Email: knitter@geographie.uni-kiel.de 

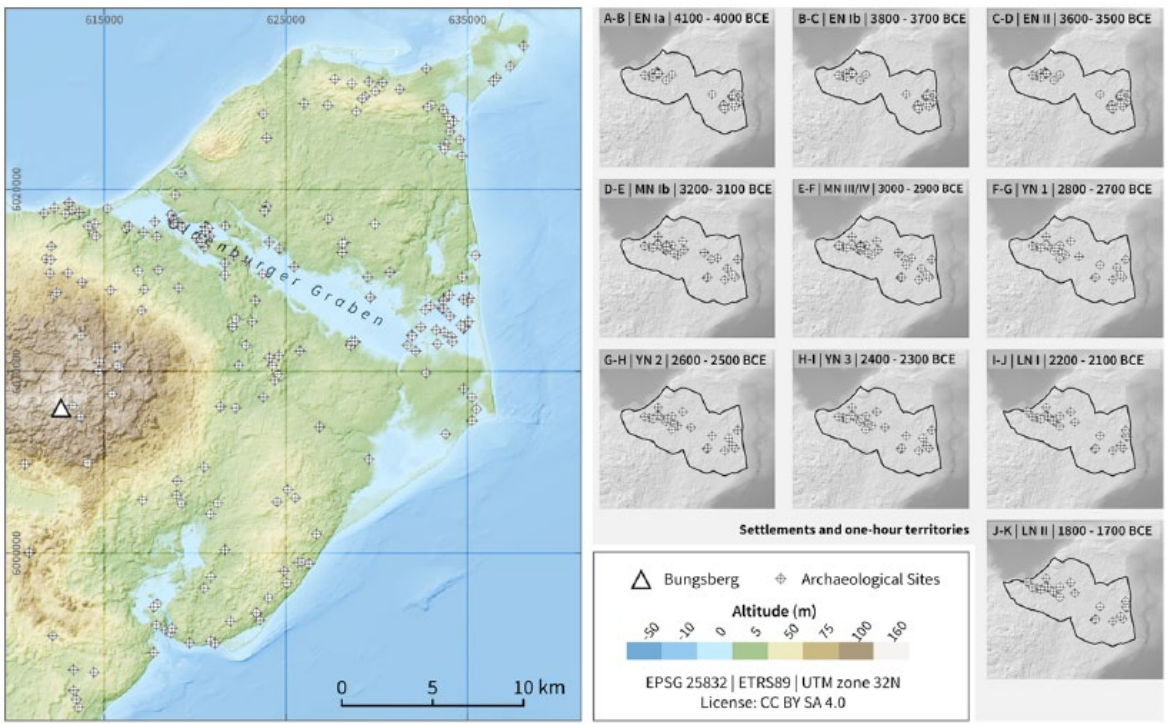

Figure I. (Left) General overview of the study area; (right) employed Neolithic settlement location for the subsequent analyses with their corresponding I-h territory. Those periods of cultural change and accompanied transformations are shown, whose model results are given in Figures 4 and 6. Exact amount of settlements is given in Table I.

(164 m; Figure 1) in the West. The surroundings of the Oldenburger Graben are characterized by a gently rolling ground moraine relief (Meynen and Schmithüsen, 1962), with glacierinduced, formerly calcareous, till deposits. Post-glacial decalcination and subsequent loamification lead to the development of Luvisols (Horn et al., 2006), Cambisols, Gleysols, and Histosols (Fränzle, 2004). In general, there is a tendency of soil acidification in the area that started with the onset of the Holocene.

The time span considered here is climatically characterized by a transition from the Atlantic (ca. 6800-3800 BCE) to the Subboreal period (ca. 3800-700 BCE; Nelle and Dörfler, 2008: 57 ff.). This transition is characterized by generally decreasing temperatures (Böse et al., 2018: 162) and wetter climatic conditions (Barber et al., 2004; see also for recent discussions Krossa et al., 2017; Warden et al., 2017).

The Oldenburger Graben area, characterized by lakes and swampy depressions, underwent marked changes during the late glacial and early Holocene. Because of postglacial sea-level rise, the late Atlantic shallow firth of the Baltic was flooded from around $6000 \mathrm{BCE}$ onward, with an oscillating rise between $4800 \mathrm{BCE}(-4$ $\mathrm{m}$ a.s.l.) and $2700 \mathrm{BCE}$ (-1.5 m a.s.l.; Jakobsen, 2004). Accompanying coastal erosion caused spit formation that blocked the former bay and lead to the development of a brackish lagoon during the Neolithic. Limnic sedimentation in the western part of the Oldenburger Graben started around 2700 BCE (in the pollen diagram Kleinwessek marked by a decrease of Chenopodiaceae and Hystrix and an increase in Sparganium-type Figure 3; Supplemental Material $\mathrm{B}$ available online). In the eastern part, this sedimentation was interrupted by a second marine phase, and was finally cut off from the Baltic Sea around 2500-2000 BCE (Jakobsen, 2004).

\section{Archaeological characteristics of the study area}

The Oldenburg Graben has been the focus of Mesolithic and Neolithic research projects since the 1950s because of its exceptionally good preservation conditions for archaeological archives. As a result, the data available for this study is comprised of 63 domestic sites as represented mostly by surface finds (Hoika, 1987; Karnatz, 1987; Mennenga, 2016) and some excavated domestic sites with primarily wet conservation $(n=7)$ from the Late Mesolithic (Goldhammer et al., 2008; Hartz, 1999) to the Late Neolithic (Brozio, 2016; Brozio et al., 2018; Glykou, 2011; Hartz, 2002; Hoika, 1972, 1986, 1987; Meurers-Balke, 1983).
Within the late Mesolithic and Neolithic societies of the South Cimbrian Peninsula, we observe different societal transformations which are most probably linked to environmental, technological, and ideological changes (Müller, 2013, 2014). We thus identify periods of relative stability (labeled $\mathrm{A}, \mathrm{B}$, etc.) that alternate with transformation phases (labeled $\mathrm{A}-\mathrm{B}, \mathrm{B}-\mathrm{C}$, etc.) characterized by increasing discontinuities within the archaeological record.

Thus, the Neolithic socio-cultural groups that are considered here can be related to 10 particular transformation phases, which lead to diverse reorganization of economic and social processes, through the introduction of new social, cultural, and/or material characteristics (Brozio et al., 2012, 2017; Müller, 2013, 2014; Müller and Peterson, 2015; Table 1)2:

- The late northern foragers with their specialization in aquatic resources had their first contacts ca. $5100 \mathrm{BCE}$ with southern Neolithic groups (Hartz et al., 2011; Klassen, 2004) and developed from 4800 BCE onward a more specialized adaptation to environmental and cultural efforts, expressed in the regular use of pottery. This period (Late Ertebölle, period $A$ ) included contacts to farming societies that terminated in transformation phase $A-B$ around 4100 BCE (Andersen, 2000; Glykou, 2011). During a potential supra-regional climate deterioration (Dreibrodt et al., 2010), the widening of the communication networks enhanced the introduction of cultivars and domesticates, and the introduction of adzes as well as flat based Funnel Beakers.

- The earliest Funnel Beaker period $B$ was non-monumental; archaeological remains are still sparse. The construction of monumental architecture started with non-megalithic long-mounds around 3800 BCE (Müller et al., 2014) that changed the cultural landscape (phase $B-C$ ). Woodland opening due to cattle grazing developed, but arable farming was practiced only sporadically.

- The construction of first enclosures and megaliths in period $C$ were still linked with horticultural practices. The subsequent transformation phase $C-D$ is characterized by an increase in such monuments (Dibbern, 2015; Hage, 2016), especially the boom of megalithic graves (Fritsch et al., 2010; Hinz et al., 2012). In addition, an increasing opening of the woodlands takes place (Feeser et al., 2012) around $3600 \mathrm{BCE}$. This goes along with an extensification 
Table I. Detailed archaeological chronology, phases of relative stability (A, B, etc.) and transformations (A-B, B-C, etc.) with diet composition as derived from nutrient requirement analysis.

\begin{tabular}{|c|c|c|c|c|c|c|c|c|c|c|c|c|c|}
\hline \multirow{2}{*}{$\begin{array}{l}\text { Group/ } \\
\text { culture }\end{array}$} & \multirow[t]{2}{*}{ Period } & \multirow[t]{2}{*}{ Phase } & \multirow{2}{*}{$\begin{array}{l}\text { Phases of relative } \\
\text { stability and } \\
\text { transformations }\end{array}$} & \multirow{2}{*}{$\frac{\text { Start }}{\text { cal. BC }}$} & \multirow{2}{*}{$\begin{array}{l}\text { End } \\
E\end{array}$} & \multicolumn{2}{|l|}{ Plants (\%) } & \multicolumn{2}{|l|}{ Fish (\%) } & \multicolumn{2}{|c|}{ Animals (\%) } & \multirow{2}{*}{$\begin{array}{l}\text { People per } \\
\text { settlement }\end{array}$} & \multirow{2}{*}{$\begin{array}{l}\text { Number of } \\
\text { settlements }\end{array}$} \\
\hline & & & & & & Gathered & Domestic & Marine & Fresh & Hunted & Domestic & & \\
\hline \multirow[t]{12}{*}{ Ertebölle } & Final & $\mathrm{FM}$ Jae & $A$ & 5300 & 5200 & 2 & 0 & 22 & 74 & 2 & 0 & 10 & 52 \\
\hline & Mesolithic & & & 5200 & 5100 & 2 & 0 & 22 & 72 & 4 & 0 & 10 & \\
\hline & & FM Ros & & 5100 & 5000 & 4 & 0 & 22 & 70 & 4 & 0 & 10 & \\
\hline & & & & 5000 & 4900 & 5 & 0 & 22 & 66 & 7 & 0 & 10 & \\
\hline & & & & 4900 & 4800 & 6 & 0 & 22 & 64 & 8 & 0 & 10 & \\
\hline & & FM Jar & & 4800 & 4700 & 7 & 0 & 22 & 62 & 9 & 0 & 10 & \\
\hline & & & & 4700 & 4600 & 9 & 0 & 22 & 57 & 12 & 0 & 10 & \\
\hline & & & & 4600 & 4500 & 10 & 0 & 22 & 54 & 14 & 0 & 10 & \\
\hline & & FMTim & & 4500 & 4400 & 12 & 0 & 22 & 51 & 15 & 0 & 10 & \\
\hline & & & & 4400 & 4300 & 14 & 0 & 22 & 47 & 17 & 0 & 10 & \\
\hline & & & & 4300 & 4200 & 14 & 0 & 22 & 43 & 19 & 2 & 10 & \\
\hline & & & $A-B$ & 4200 & 4100 & 16 & 0 & 22 & 40 & 20 & 2 & 10 & \\
\hline Funnel & Early & EN la & & 4100 & 4000 & 11 & 9 & 22 & 32 & 10 & 16 & 10 & 95 \\
\hline \multirow[t]{12}{*}{ Beaker } & Neolithic & & B & 4000 & 3900 & 11 & 11 & 22 & 28 & 10 & 18 & 10 & \\
\hline & & & & 3900 & 3800 & 11 & 11 & 21 & 28 & 10 & 19 & 10 & \\
\hline & & EN lb & $B-C$ & 3800 & 3700 & 11 & II & 21 & 28 & 10 & 19 & 10 & \\
\hline & & & C & 3700 & 3600 & 11 & 11 & 21 & 28 & 10 & 19 & 10 & \\
\hline & & EN II & C-D & 3600 & 3500 & 3 & 20 & 20 & 27 & 10 & 20 & 10 & \\
\hline & & & $D$ & 3500 & 3400 & 3 & 21 & 19 & 27 & 9 & 21 & 10 & \\
\hline & Middle & $\mathrm{MN}$ la & & 3400 & 3300 & I & 23 & 18 & 26 & 3 & 29 & 20 & 113 \\
\hline & Neolithic & & & 3300 & 3200 & I & 24 & 17 & 26 & 3 & 29 & 20 & \\
\hline & & MN Ib & $D-E$ & 3200 & 3100 & I & 23 & 17 & 25 & 2 & 32 & 40 & \\
\hline & & MN II & $E$ & 3100 & 3000 & 2 & 23 & 17 & 24 & 2 & 32 & 60 & 117 \\
\hline & & MN III-IV & $E-F$ & 3000 & 2950 & 3 & 21 & 18 & 24 & 3 & 31 & 30 & 134 \\
\hline & & MNV & $\mathrm{F}$ & 2950 & 2800 & 3 & 20 & 18 & 26 & 10 & 23 & 20 & 110 \\
\hline Single & Younger & YN I & $\mathrm{F}-\mathrm{G}$ & 2800 & 2700 & 5 & 19 & 17 & 28 & 11 & 20 & 10 & 111 \\
\hline \multirow[t]{5}{*}{ Grave } & Neolithic & & $\mathrm{G}$ & 2700 & 2600 & 5 & 20 & 16 & 30 & 11 & 18 & 10 & \\
\hline & & YN 2 & G-H & 2600 & 2500 & 9 & 18 & 15 & 28 & 11 & 19 & 10 & \\
\hline & & & $\mathrm{H}$ & 2500 & 2400 & 9 & 19 & 15 & 26 & 11 & 20 & 10 & \\
\hline & & YN 3 & $\mathrm{H}-\mathrm{I}$ & 2400 & 2300 & 6 & 23 & 15 & 24 & 11 & 21 & 10 & \\
\hline & & & 1 & 2300 & 2200 & 7 & 23 & 15 & 22 & 12 & 21 & 10 & \\
\hline \multirow[t]{5}{*}{ Dolktid } & Late & LN I & $1-J$ & 2200 & 2100 & I & 30 & 15 & 20 & 15 & 19 & 10 & 101 \\
\hline & Neolithic & & J & 2100 & 2000 & I & 33 & 14 & 17 & 16 & 19 & 10 & \\
\hline & & & & 2000 & 1900 & 1 & 33 & 14 & 17 & 16 & 19 & 10 & \\
\hline & & LN II & & 1900 & 1800 & I & 34 & 13 & 16 & 16 & 20 & 10 & \\
\hline & & & $J-K$ & 1800 & 1700 & I & 35 & 13 & 15 & 16 & 20 & 10 & \\
\hline
\end{tabular}

FM: Final Mesolithic; EN: Early Neolithic;YN:Young Neolithic; LN: Late Neolithic.

of crop growing on large arable fields and the introduction of the ard as an important technological innovation in agriculture (Kirleis \& Fischer 2014).

- Period $D$ is the main construction phase for megaliths (Hinz et al., 2012; Müller, 1998, 2011). The intensified use of copper tools and the increasingly elaborated ceramic designs are characteristic of supra-regional as well as regional innovations (Klassen, 2001). A regional demographic growth (Brozio, 2016) and a regional to supra-regional increase of weapons in burials (Müller, 2011 ) around $3200 \mathrm{BCE}$ is apparent. The transformation phase $D-E$ that followed this boom period is characterized by a decline in regional ceramic designs, the end of the construction of megaliths, and the introduction of new supra-regional pottery designs.

- During the subsequent centuries (period E), Funnel Beaker communities re-used previously existing megaliths for secondary burials without erecting new ones. The period is characterized by an increase of depositions, in particular axes and adzes, within the landscape.

- The end of the funnel beaker societies $($ period $F)$ is characterized by the occurrence of the Store-Valby style around $3000 \mathrm{BCE}$ as well as the appearance of the phenomenon of the globular amphorae (Brozio, 2016; Hoika, 1987; Klooß, 2008; Müller and Peterson, 2015; Sørensen, 1998).

- The appearance of Single Grave groups around 2850 BCE (Hübner, 2005; Schultrich, 2018; Struve 1955) with first barrows for individual burials describes the transformation to differently organized societies (phase $F-G$ ).

- The early Young Neolithic with the early Single Grave Culture and latest Store-Valby ceramic groups displays in general a boom in new monumental activities (period $G$ ). Around $2600 \mathrm{BCE}$, with the end of the existence of the Store-Valby groups, the reduction in mound building and deposition of the axes phase $G-H$ changed the conditions again (Hübner, 2005).

- Since 2500 BCE, the latest Single Grave Groups did practice mainly secondary burials in megaliths or in earlier barrow mounds (period $H$ ). In contrast to earlier Corded Ware phases, now the integration of females into the representation of public space is practiced (Furholt, 2016). The increasing Bell Beaker influence (Mertens, 2003) and the introduction of new methods of flint production 
signifies the transformation to the Late Neolithic (phase $H-I$ ) around $2400 \mathrm{BCE}$.

- Since $2300 \mathrm{BCE}$, the dominance of new methods of flint processing (Höfgen, 2014; Vandkilde, 1996) appears in the form of regionally retouched objects (period I). Supraregionally, this period displays increasing contact that might be responsible for the starting regional metal production. Around $2200 \mathrm{BCE}$, the transformation phase I-J is observed: in contrast to the Late Neolithic, an intensification of barrow construction and the dominance of metal production signifies the decreasing role, for example, flint processing played later on.

- A complete adaptation to the use of metal takes place in the Bronze Age (period $K$ ).

\section{Methods and data}

Extensive archaeological data are available for the Oldenburger Graben area, in particular for the Neolithic period (Figure 1; Table 1).

The available archaeological data derive from the manifold investigations and surveys that covered the whole area (Brozio, 2016; Brozio et al., in press; Glykou, 2011; Goldhammer et al., 2008; Hartz, 1999, 2002; Hoika, 1972, 1986, 1987; Karnatz, 1987; Mennenga, 2016; Meurers-Balke, 1983). The data basis relies on selected domestic sites and includes the results from recent excavations and radiometric dating programs that were analyzed by use of the aoristic method (Johnson, 2004; Mischka, 2004; Ratcliffe, 2000; Ratcliffe and McCullagh, 1998). As the size of the sites in the different periods and phases is known from target excavations of key sites, which enabled also the calculation of population figure, demographic values could be transferred to the test area Oldenburger Graben (Table 1).

To model the required extent of areas for the different landuse practices, nutrient requirements and dietary composition have to be outlined here, since the land-use model is based on the calculation of caloric requirements for the population and settlements. A second precondition for calculating the land-use model is the establishment of a fuzzy model of the potential vegetation and land-use, to enable the linking of certain land-use practices with specific growth conditions for woodlands and distance to settlements. Based on the two components, (a) nutrient requirements and dietary composition assumptions and (b) the fuzzy-vegetation-model, the quantitative reconstruction of land-use is calculated.

\section{Nutrient requirements and proposed dietary composition}

A non-trivial problem for the reconstruction of prehistoric subsistence economies is the reconstruction of the relative ratios of the nutritional components. The challenge is that it is not possible to assess to which degree the empirical data (quantities of animal bones, plant species, and their ratios quantities and nutritional components) mirrors the real distribution at a given time. Schibler et al. (1997) already drew attention to this problem during the reconstruction of 'real' herd sizes from the bone populations of the alpine lakeshore settlements (cf. Schibler, 2008). Corresponding calibration problems also arise with the evaluation of the vegetation composition based on pollen data, although algorithmic support such as LOVE and REVEALS might offer a solution (cf. Sugita, 2007a, 2007b performed in Diers, 2018; Trondman et al., 2015; and Marquer et al., 2014). From an archaeological point of view, it is also difficult to transform quantities of means of production (if discovered, for example, millstones or slaughtering equipment) into real numbers of existing herds or grain quantities.
In order to escape this dilemma, we employ the FRUITS software which converts stable isotope components into nutritional models. Based on the different stable isotope values of different food components as recorded in human bones, it allows the calculation of proportions of the consumed food components (Fernandes et al., 2014; Fernandes et al., 2012). One example for the application of FRUITS is the Southern Scandinavian Neolithic, where a modeling of nutritional values was carried out for the Falbygden area (Sjögren, 2017). FRUITS is flexible and is able to formulate different conditions, for example, to calculate the stable isotope values of the investigated human (target data) from the different stable isotope signals of, for example, sea fish, cereals, or mammals (i.e. the source values).

These source values rely on modern comparative values, for which intensive studies are available, or from observed differences in prehistoric, non-human bones (Bogaard et al., 2013; Fernandes et al., 2015; Fischer et al., 2007). Although investigations are available to improve the baseline of the analysis, it is still difficult to distinguish between wild and domestic animals or collected and cultivated plants. However, even if the information gained from these isotope analysis are not very specific and on a general level, they are a great help for the relative quantification of different nutrition components.

For the calculation of the food components, 22 radiocarbon datings with additional extra measurements of $\delta^{13} \mathrm{C}$ and $\delta^{15} \mathrm{~N}$ are used (Supplemental Material A available online). The radiometric dates are distributed mainly between 4000 and 2000 BCE and originate from different ecological zones, so that a differentiation in the exploitation of marine and terrestrial food sources is to be expected. Even if the number of isotope samples with respect to the temporal duration of the investigated developments is small, the results can be considered as robust since no contradictions are visible within the investigated area.

The employed values for stable isotope components for the combined food groups terrestrial animals, freshwater fish, and marine fish are derived from the mean values provided in Terberger et al. (2018). The latter are the adjusted values based upon data published by Fernandes et al. (2015) and Fischer et al. (2007). Since no correction factors are available for the values of plants (as published in Bogaard et al., 2013), we transferred the correction values of the other food components.

A distinction between cultivated and collected plants, as well as between domestic and wild animals, is not possible. Accordingly, percentages of corresponding animal bone compositions and plant inventories, as published in Steffens (2007), Kirleis et al. (2012), and Brozio et al. (in press), are used.

The proportions of domestic versus gathered plants per period are calculated using seeds and fruits from different settlement sites in northern Germany (Kirleis et al., 2012, data from Tables 1 and 2; Brozio et al., in press; Effenberger, 2018; Supplemental Material $\mathrm{C}$ available online). The data set shows some limitations, because deposition processes and taphonomic issues vary from site to site depending on (a) different past human activities, (b) preservation conditions, as well as (c) the specific nature of the remains. Thus, the data are harmonized to make it comparable and representative (Supplemental Material C available online).

\section{Fuzzy model of potential vegetation and land use}

To identify areas that are most suitable for the different land-use activities, we use a fuzzy rule-based system. The model relates the potential for certain land-use practices to (a) their distance to settlements as well as (b) living conditions for certain forest types. The latter is chosen because vegetation is sensitive to the topographic situation as well as soil characteristics. Besides, thanks to available pollen archives, we are able to test whether the spatial model of forest distribution matches the prevailing conditions of the focused time periods. 


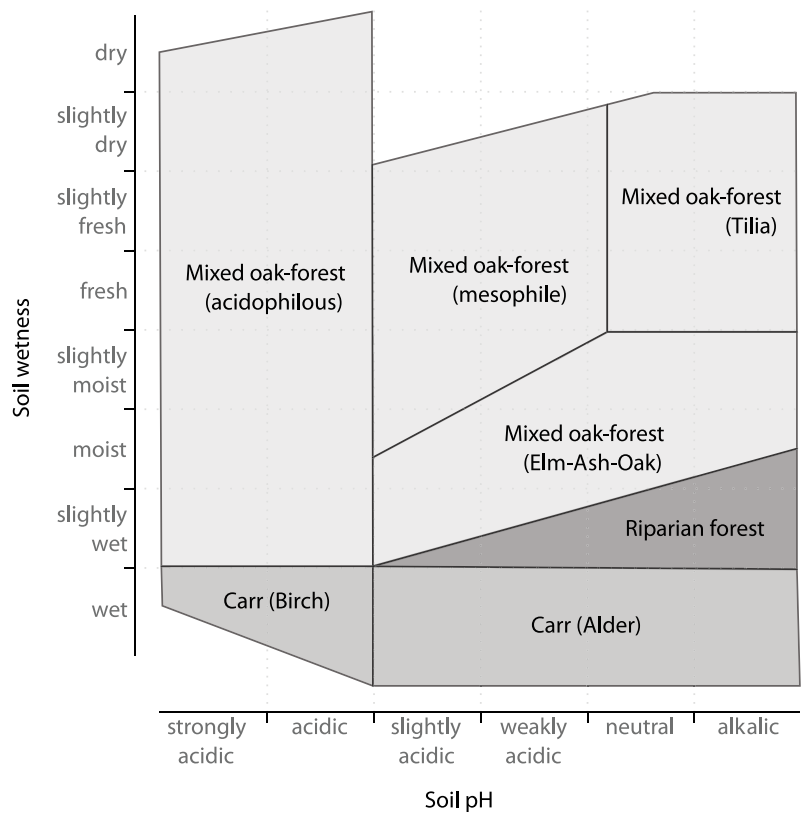

Figure 2. Ecogram for potential Mesolithic and Neolithic woodland, modified and simplified based on Ellenberg and Leuschner (2010).

Fuzzy logic, introduced by Zadeh (1965), helps to classify data where clear borders are hard to establish. The general idea is that rather than assigning values to a particular class they are assigned a value that measures their degree of belonging to a particular class. This membership degree often ranges between 0 (i.e. the value does not belong to the fuzzy class) and 1 (i.e. the value belongs completely to the fuzzy class; further general information about the methodology are given by, for example, Demicco, 2004 or Klir and Yuan, 1995). Fuzzy methodology, though already quite aged, currently has only a few applications in landscape archaeology; examples range from site location analysis (e.g. Jasiewicz and Hildebrandt-Radke, 2009; Popa and Knitter, 2015), viewshed methods (e.g. Loots et al., 1999) or chronology (e.g. Nakoinz, 2012). We employ the R package FuzzyLandscapes (Hamer and Knitter, 2018), inspired by Jasiewicz (2011), to analyze a raster-based fuzzy rule-based system.

The regional fuzzy classification of forest types is based on locational requirements of certain woodland communities (Figure 2). The input data for this model are soil and sediment information (provided by Landesamt für Landwirtschaft, Umwelt und ländliche Räume Schleswig-Holstein) as well as digital elevation model (DEM, provided by the Landesamt für Vermessung und Geoinformation Schleswig-Holstein; aggregated to $10 \times 10 \mathrm{~m}$ ) with derived geomorphometric parameters including the Saga Wetness Index (Böhner and Selige, 2006) and the slope. Sand, silt, clay, and humus contents are regionalized using a kriging algorithm (Pebesma, 2004) prior to fuzzification. A fuzzy rulebased system is defined using these data to calculate acidity classes (Supplemental Material D available online). Acidity classes and wetness information, derived from the Saga Wetness Index, are combined to a second fuzzy rule-based system, which produces forest type classes according to locational preferences as defined according to Ellenberg and Leuschner (2010), with an adjustment to the study area and the investigated time (Figure 2). The resulting fuzzy sets are spatial representations of the potential suitability for different vegetation units. The suitability for agricultural use is implemented using distance to settlements, as well as soil and wetness information (Supplemental Material D available online). In addition, a 'light forest' class is defined which represents a great suitability for mixed oak forest, as derived from the adapted ecogram, and a close distance to the settlements.

\section{Pollen data for evaluation of the fuzzy model}

In order to assess the quality of the fuzzy vegetation model, we use pollen information. Pollen data from the Oldenburger Graben are available from several on- and off-site analyses (Averdieck, 2004; Kalis and Meurers-Balke, 1998; Meurers-Balke, 1983, 1997; Venus, 2004). As on-site data are of very local explanatory value, we focus this study on the regional pollen record from Klein Wessek by Venus (2004; Figure 3; Supplemental Material B available online). This study was carried out in the 1960s and no ${ }^{14} \mathrm{C}$-data are available. Thus, the time-depth model is based on regional pollen stratigraphic events, with corresponding temporal uncertainties (cf. Dörfler et al., 2012; Feeser et al., 2012). Since pollen data give a distorted picture of the real vegetation and its quantitative distribution because of variable pollen productivity and transport between species, there is the need for quantification of vegetation if we want to compare it with results of the fuzzy model. Different approaches are available to calibrate pollen data (Mrotzek et al., 2017; Sugita, 1998; Sugita et al., 1999; Theuerkauf and Couwenberg, 2017). Here, we applied the pollen-calibration algorithm of REVEALS (Sugita, 1998) as implemented in the DISQOVER v.09 package (Theuerkauf et al., 2016) with the pollen productivity estimates from Mecklenburg-Vorpommern (PPE_MV2105). The curves show the summed quantified proportion of mesophile arboreal taxa (Quercus, Ulmus, Tilia, Fraxinus, Fagus, and Carpinus) and the summed quantified proportion of light-demanding arboreal taxa (Corylus, Betula, Rosaceae). As a third curve, we included the landscape openness indicator curve that is suggested as independent palynological human impact proxy (Feeser et al., this issue). Here, the predicted spectra score values for the data of Klein Wessek using the result of a principal component analyses (PCA) are used to reconstruct the human impact on the vegetation for northern Germany during the Neolithic and Bronze Age (cf. Dörfler et al., 2012; Feeser and Dörfler, 2015; Feeser et al., this issue, 2012).

\section{Quantitative reconstruction of past land use}

Because of the fragmentary material remains and complex decision and value systems of past societies, any attempts to quantify past land-use patterns have to be seen as heuristics of past realities, rather than precise reconstructions (cf. Oreskes et al., 1994). We reconstruct past land-use based on the approach published by Hughes et al. (2018) via the R package LandUseQuantifieR (Knitter et al., 2018). Based on an assumption about the general caloric requirement of an individual with an active lifestyle, an assumed household size of five people, and information on population size, the caloric requirements of the settlements are calculated. These values are combined with the data on diet characteristics (see methods 'Nutrient requirements and proposed dietary composition') and information on the energy density (kcal/ha) of plants and animals in order to assess the minimum area that is required to fulfill the caloric needs of the population (see Supplemental Material $\mathrm{E}$ available online).

To reconstruct the productivity of prehistoric crop growing, we refer to data from a growth experiment on permanent plots at Hambacher Forst with the Neolithic cereals emmer, einkorn, and barley, grown as summer crops in 1979 (Lüning and MeurersBalke, 1980). Further long-term experiments reveal barley yields of $1000 \mathrm{~kg} / \mathrm{ha}$ in southern Lower Saxony and $730 \mathrm{~kg} / \mathrm{ha}$ for eastern Prussia.

The calculations of dietary needs and population size rely on the main components of those crops that were present in the focused time, which are emmer and barley, with an additional minor component provided by the oil plants linseed and poppy. For the gathered plants, crab apple and hazel are taken into consideration. Wild apple was an important staple fruit in the Neolithic (Antolín et al., 2016; Brozio et al., 2014; Cornille et al., 


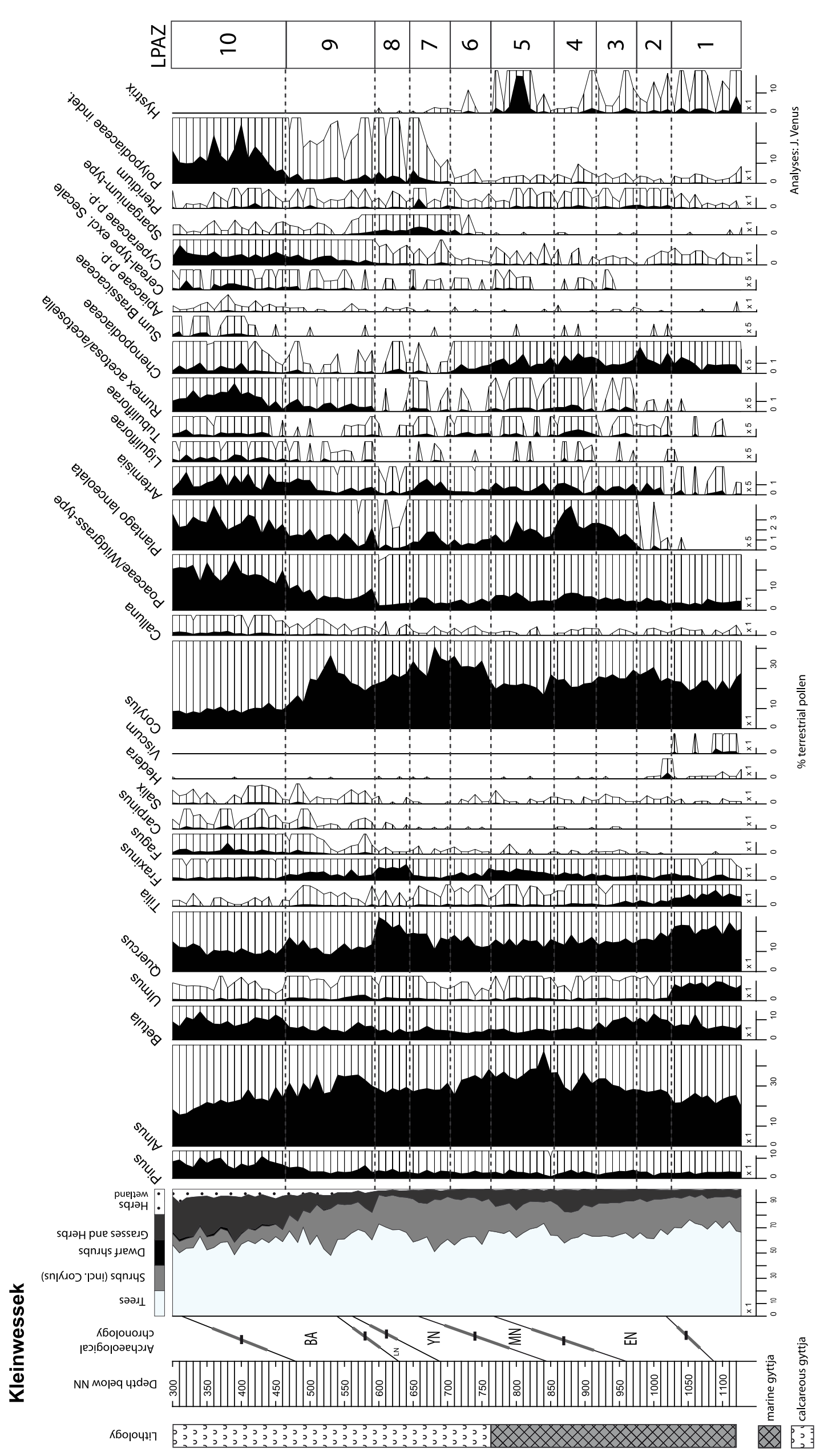


2019; Kirleis, 2018). For reasons of preservation, storage of crab apples most possibly was arranged with dried fruits. Thus, we consider here the caloric values for dried apples, which show a five-fold enrichment in caloric content if compared to fresh fruits. The caloric data are compiled mainly from Souci et al. (2016), where information on nutrient and energy densities of species in the focused time were absent, modern data are used (see Knitter et al., 2018 for nutrient tables and corresponding references as well as Supplemental Material E available online).

Land-use activities are considered to take place in an area that is up to one walking hour distant from the individual sites (Figure 1 , right). Distance is based on real-surface distance as calculated using the r.walk algorithm in GRASS GIS. The value of $1 \mathrm{~h}$ is variable, but is selected here since it has some empirical and diachronic grounding (e.g. Marchetti, 1994). The individual 1-h settlement territories are considered as zone of activity for the subsequent mapping of land-use types. This is done by selecting all areas that are part of any 1-h territory around the individual settlements. Accordingly, land-use maps are not settlement but area-specific.

\section{Results}

\section{Nutrient requirements and proposed dietary composition}

The calculations of the nutrition values for the individual periods and phases show (Table 1; Supplemental F available online) that aquatic resources are continuously used with the greatest importance during Mesolithic times. The proportions of collected plants and wild animals show a similar trend (Supplemental Material C available online). The increasing importance of animal resources in the third millennium BCE corresponds to the interpretations from supra-regional studies (cf. Heyd, 2017).

The results from modeling the nutrient requirements are based on the diversity of food sources utilized (Table 1; Supplemental E available online). The calculations for resources including fish, game, and plants based on the nutrient requirement and dietary components data (Figure 5c) suggest various strategies of land use. During the Late Mesolithic, the values show a predominant use of game and collected plants, whereas marine resources play a subordinate role. During the Neolithization phase $(B-C)$, the proportions decrease until a proportionally greater use of marine resources can be observed around $3100 \mathrm{BCE}(\mathrm{E})$. Thus, it becomes clear that not only in the Mesolithic or at the beginning of the Neolithic the exploitation of wild plants, hunting, and fishing was important, but it contributed to food supply much further out into the Middle Neolithic period and beyond, and it was especially incorporated at the time of the enlarged Middle Neolithic Funnel Beaker settlements; this is indirectly confirmed by the frequent occurrence of (radiocarbon-dated) fish weirs, for example, in the Danish record (cp. Oleslyst; Pedersen, 1997). With the end of the Funnel Beaker groups (E-F) and the beginning of the Single Grave groups $(\mathrm{F}-\mathrm{G})$, the contribution by wild animals increases significantly again. In contrast, marine resources now occupy less proportions, but wild plants have an increasing importance in the food supply in the centuries of the Late Younger and Late Neolithic $(\mathrm{G}-\mathrm{H}$ and $\mathrm{J})$.

\section{Fuzzy mapping of potential vegetation}

The results of the fuzzy-based vegetation reconstruction show a domination of the area by mixed, oak dominated forest (dense and light forest; Figures 4 and 5a). Throughout the transformation phases, the entire area along the Oldenburger Graben is available for human appropriation as mirrored by the varying extent of light forest and agricultural land. Potential agricultural land is most extensive in the eastern part of the depression (Figure 4). Patches of very moist conditions, as represented by mires or birch dominated forests, occur frequently, and only prohibit environmental utilization in the southeastern part of the research area (Figure 4).

\section{Pollen information}

The REVEALS data give an estimate of the area covered with dense forest and with light forest from 5000 to 1000 BCE. Changes in dense woodland (Figure 5d, dashed curve) during the Early Neolithic I (A-B, B-C) are obvious: Values of around 55\% decrease to about $30 \%$ on the wider surrounding of the Klein Wessek coring site. At the same time, open woodland/light forest (Figure 5d, dotted curve) increases from about $15 \%$ to more than $20 \%$. During the Early Neolithic II (C-D, D-E), these values slowly shrink indicating an even more open landscape with little forest cover during the first half of the Middle Neolithic I (D-E). This is also represented in the fuzzy model that shows a steep increase in the 'light forest' area (Figure 5a). After 3300 BCE, a strong regeneration of dense woodland indicates decreasing human pressure on the woodland and woodland regeneration that might be explained by a change in the settlement organization (from disperse to agglomerated). This is supported by the decreasing values of the PCA results (Figure 5d, black curve) which also reflect decreasing human influence. From ca. 3200 BCE onward, human impact on the vegetation increases again, which can be interpreted as a phase of economic growth. A similar increase at around the same time is well recorded in pollen diagrams from the wider region (Feeser et al., 2012). In most pollen profiles, however, landscape openness decreases distinctly after ca. $3100 \mathrm{BCE}$ to reach a minimum at around 3000 BCE. This lull is also evident in other paleoenvironmental records (Feeser et al., this issue). At Klein Wessek, however, no corresponding lull is obvious. This points at the regional divergent development in the Oldenburger Graben. The undulating curves during the Middle Neolithic II-V (E-F) show short variances with an average woodland cover of $35 \%$ and an increasing amount of light woodland during the Middle Neolithic $\mathrm{Y}$ and Younger Neolithic I (F-G, G-H, H-I, I-J). A strong transformation is recorded in the pollen record after $2600 \mathrm{BCE}$ when dense woodland recovers and the human pressure decreases rapidly. This effect lasts for nearly 400 years until in the Late Neolithic I $(\mathrm{J}, \mathrm{J}-\mathrm{K})$ an inverse trend shows shrinking woodland cover and increasing human pressure. Similar evidence from northern Germany indicates that this strong increase in human impact on the vegetation is not restricted to the Oldenburger Graben, but is of supra-regional importance (Feeser et al., this issue).

\section{Quantitative reconstruction of past land-use per transformation phase}

The calculation of areal requirements for the land-use activities 'crops', 'pasture', 'wood', and 'arboriculture/gathered' shows that the research area is not intensively used during the focused periods (Figures $5 \mathrm{~b}$ and 6 ). With the exception of the Middle Neolithic periods and their great population number, only a fraction of the available area is used (cf. Figure $5 b$ and $d$ ).

In general, the modeled land-use in the research area is allocated in two main areas: (a) primarily the former outer firth of the eastern Oldenburg Graben, an area well suited for the cultivation of field crops, and (b) the western Oldenburg Graben. The use of the area is reflected, above all, in the extensive pasture farming (Figure 6).

The last phase of the Mesolithic (A) is characterized by the subsistence form of a gathering-hunting-fishing economy. With the transformation phase of the Neolithization from 4100 BCE (A-B) onward, this aspect of resource use slowly begins to lose importance, whereas the areas necessary for crop cultivation, 

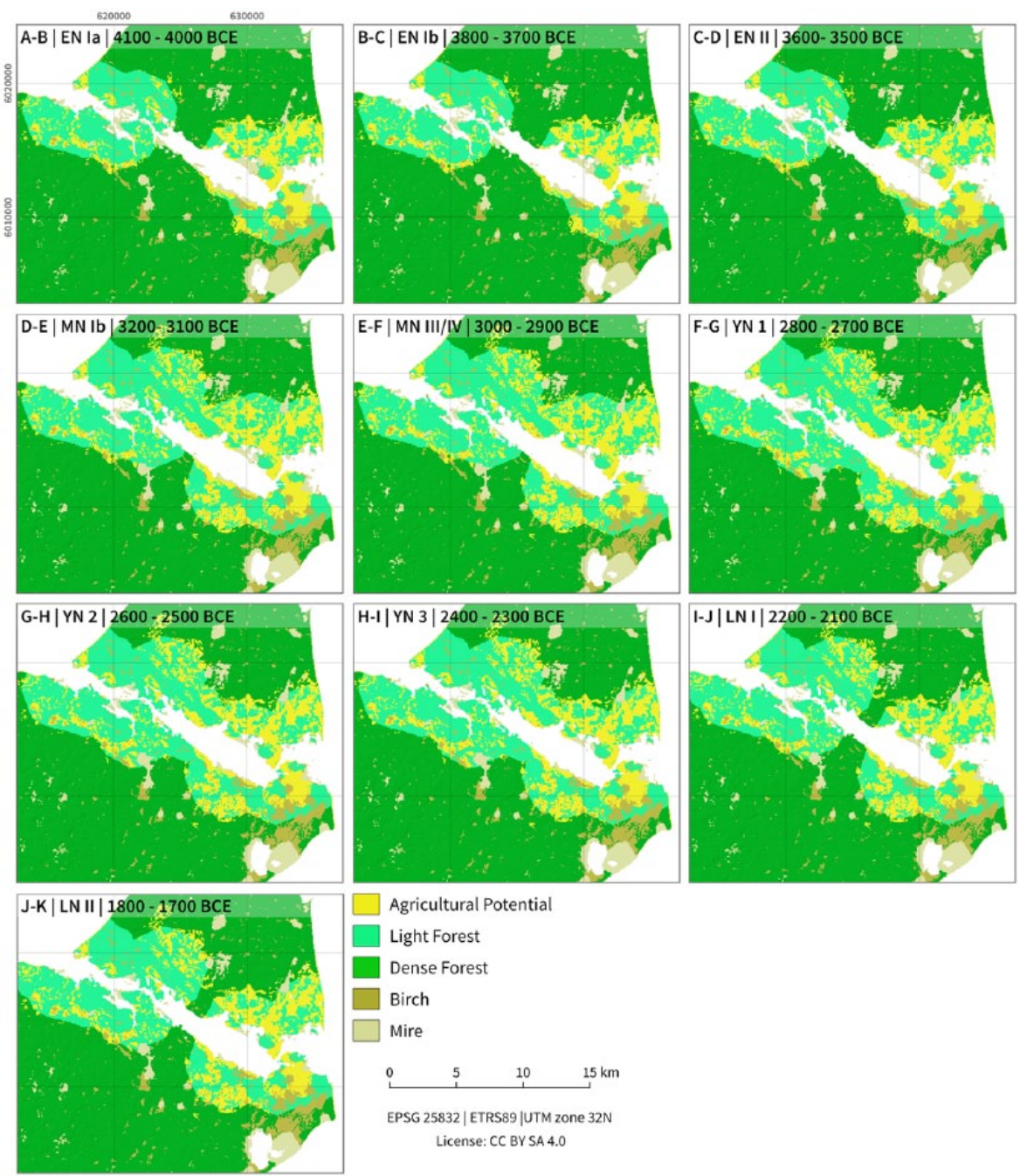

Figure 4. Results of the fuzzy model of potential vegetation. Shown are phases of cultural change and accompanied transformations (coastline is reconstructed as explained in Supplemental Material G available online; utilized number of settlements as outlined in Table I).

pastures, and managed woodland/arboriculture begin to increase in phase B (Figure 5b). At the end of the period (D-E) between 3600 and $3100 \mathrm{BCE}$, the area required for the growing of cultivars, pastures and managed woodland/arboriculture reaches its peak, and the area required to cover the needs of gathering also increases expressively again. Around $3100 \mathrm{BCE}$, a decline of the required areas in comparison to the Early Neolithic level can be observed until the beginning of the Single Grave culture groups $(\mathrm{F}-\mathrm{G})$. Although in the period of the Single Grave groups the areas of the gathering and/or managed woodland/arboriculture increased as well, a slight increase of the necessary areas for the cultivation of crops, pastures and managed woodland can be observed with the beginning of the Dagger Groups (I-J).

\section{Discussion}

The results of the land-use quantification help to gain insights into the dynamics of resource requirements and areal demands. The land-use modeled here is based on archaeological data estimating the density and size of settlements, and economic data representing the ratio of the individual food components. The model obtained is compared with vegetation data, which basically confirm the modeled development.

With respect to the simplifying assumptions and limited input data, that is, a digital elevation model and soil data, the fuzzy model of vegetation characteristics performed well. If compared with the pollen data, these correspond for the Early Neolithic I phases. For the Early Neolithic II and Middle Neolithic I, the palynological data according to Figure $5 d$ suggests an increase in woodland opening, while in the fuzzy model, the land-use components remain more or less on the former Early Neolithic I level. For the Middle Neolithic Ia, both data sets fit perfectly, showing an increase of landscape openness. In the model, the opening of the landscape increased until ca. 3000 BCE. The decrease in land openness afterward is also visible in the increase of light woodland for the Middle Neolithic V within the pollen record. However, the reverse picture with increased woodland density in Younger Neolithic 2 as well as for the Late Neolithic I as suggested by the pollen data account for a re-opening of the woodlands that is hardly visible in the fuzzy model. ${ }^{3}$

Since the fuzzy model is built upon information on settling intensity from the archaeological record (Figure 1), it fits better to the archaeological information and derived dynamics in the nutrient requirement calculations. This might offer interesting opportunities to integrate palynological and archaeological data, in order to gain a better understanding of the relevance of different archives or data sources for the assessment of the impact of human activity on the environment.

Since detailed information on individual settlements is only available for some places, the results are not site-specific but aggregated. Accordingly, the spatial distribution of different land-use areas for the Oldenburger Graben depicted in Figures 5b and 6 reflects only a theoretical scenario and should only be used comparatively to investigate diachronic dynamics. If we compare the land-use mapping based on the fuzzy results with the material culture, the Neolithic dynamics are well illustrated. Further empirical 
Phase of relative stability (A, B, etc.) and Transformation phases (A-B, B-C, etc.)

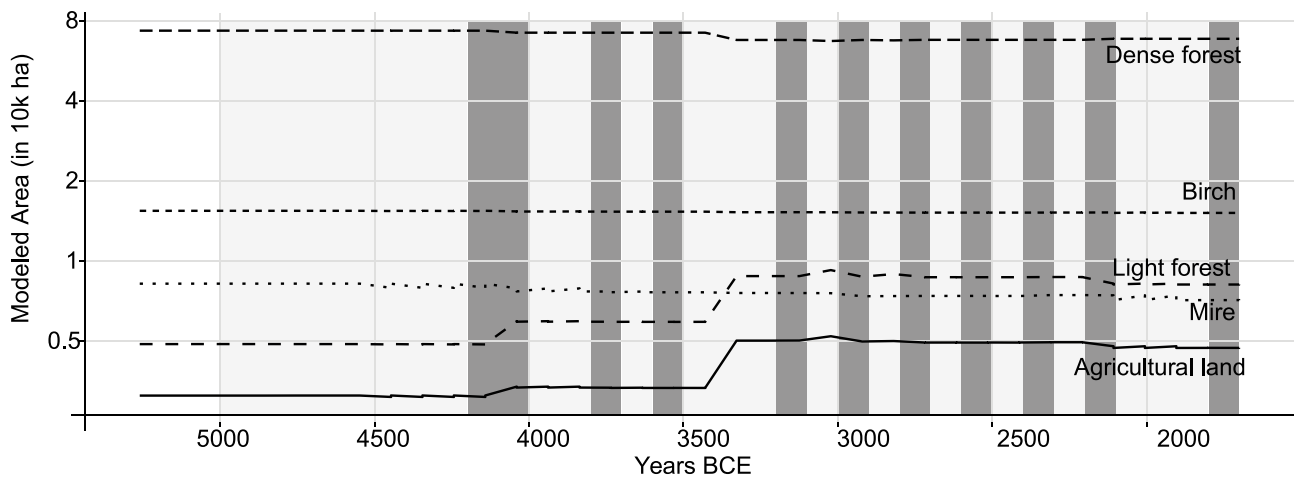

(b)
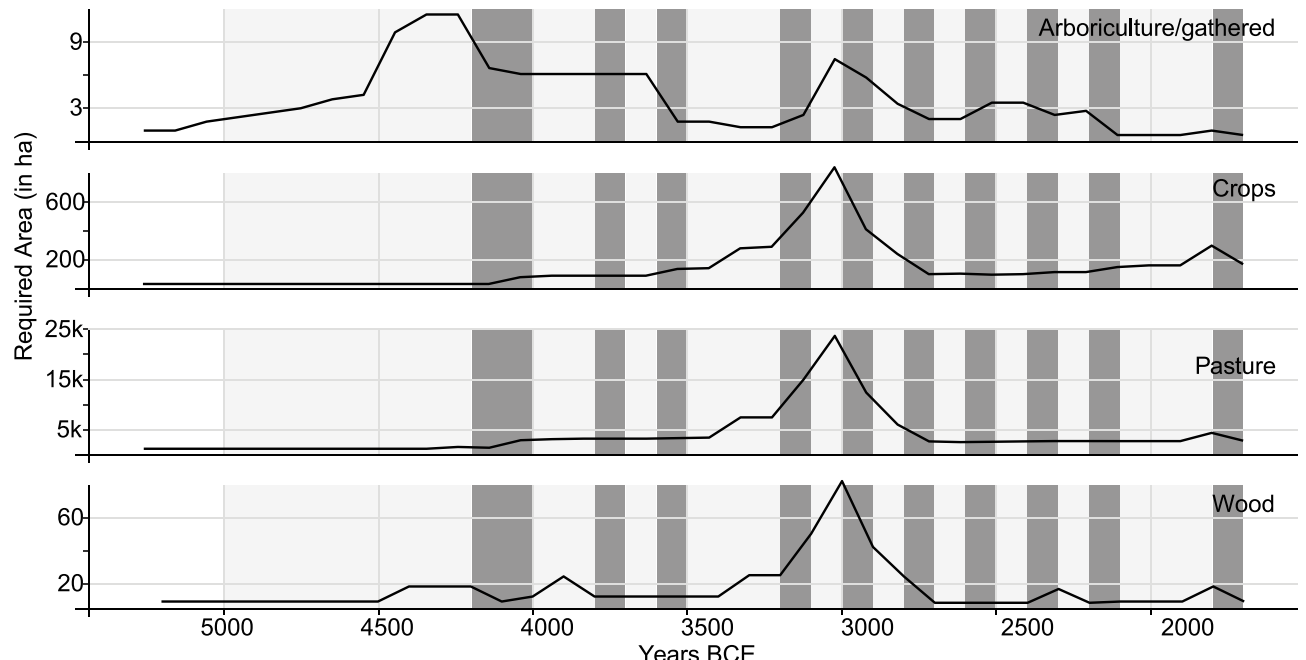

(c)

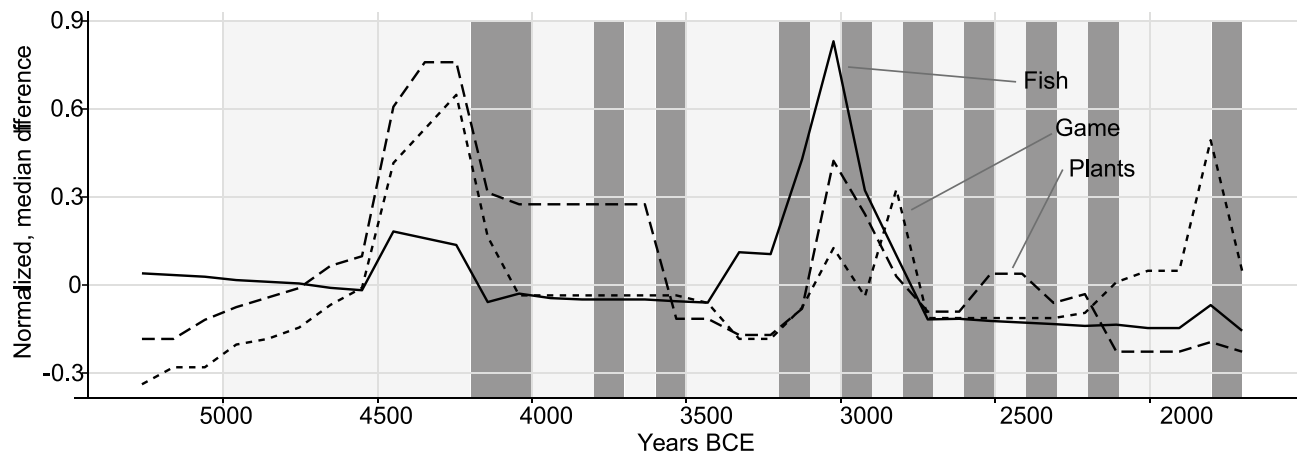

(d)

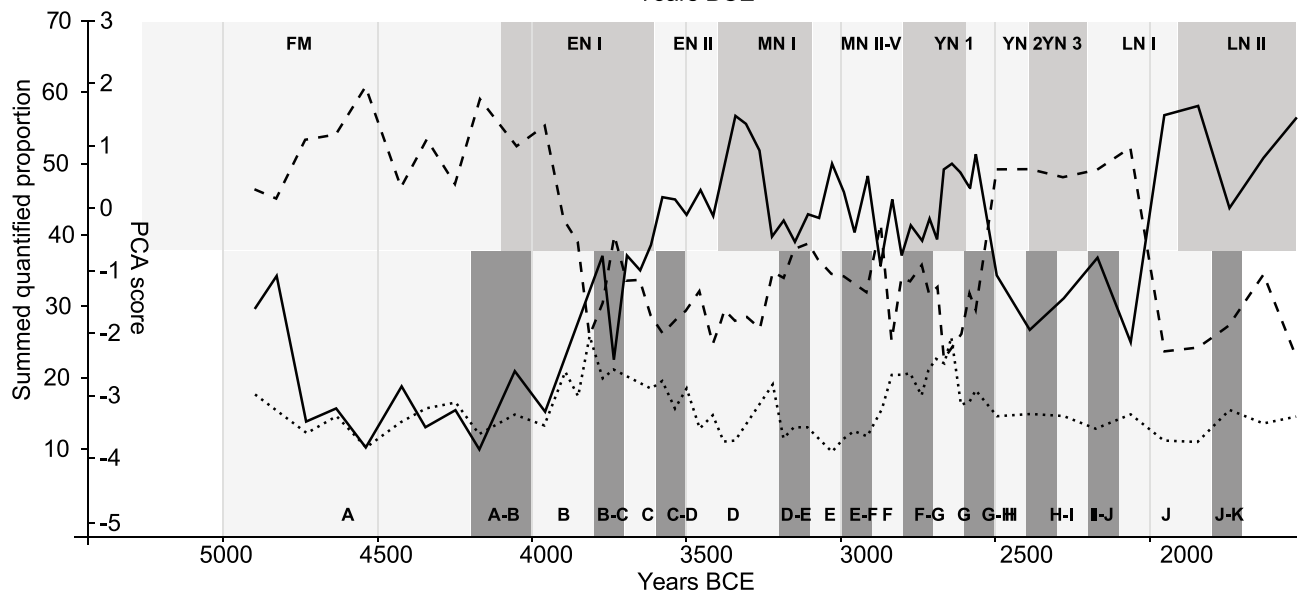

- - Summed quantified proportion of mesophile arboreal taxa (REAVEAL median, PPE: MVP2015, dwm=lsmunstable)

.... Summed quantified proportion of light demanding arboreal taxa (REAVEAL median, PPE: MVP2015, dwm=lsmunstable)

- Predicted PCA Spectra Score of first component

Figure 5. (a) Results of fuzzy vegetation reconstruction in comparison to pollen record showing change in modeled areas through time; (b) results of the quantitative reconstruction of past land-use throughout the Neolithic showing the area requirements for land-use practices over time; (c) results of the quantitative reconstruction of amounts of gathered plants and hunted animals over time; (d) human impact on the vegetation quantified by PCA using the pollen record of the Klein Wessek site (based upon data of Venus, 2004). 

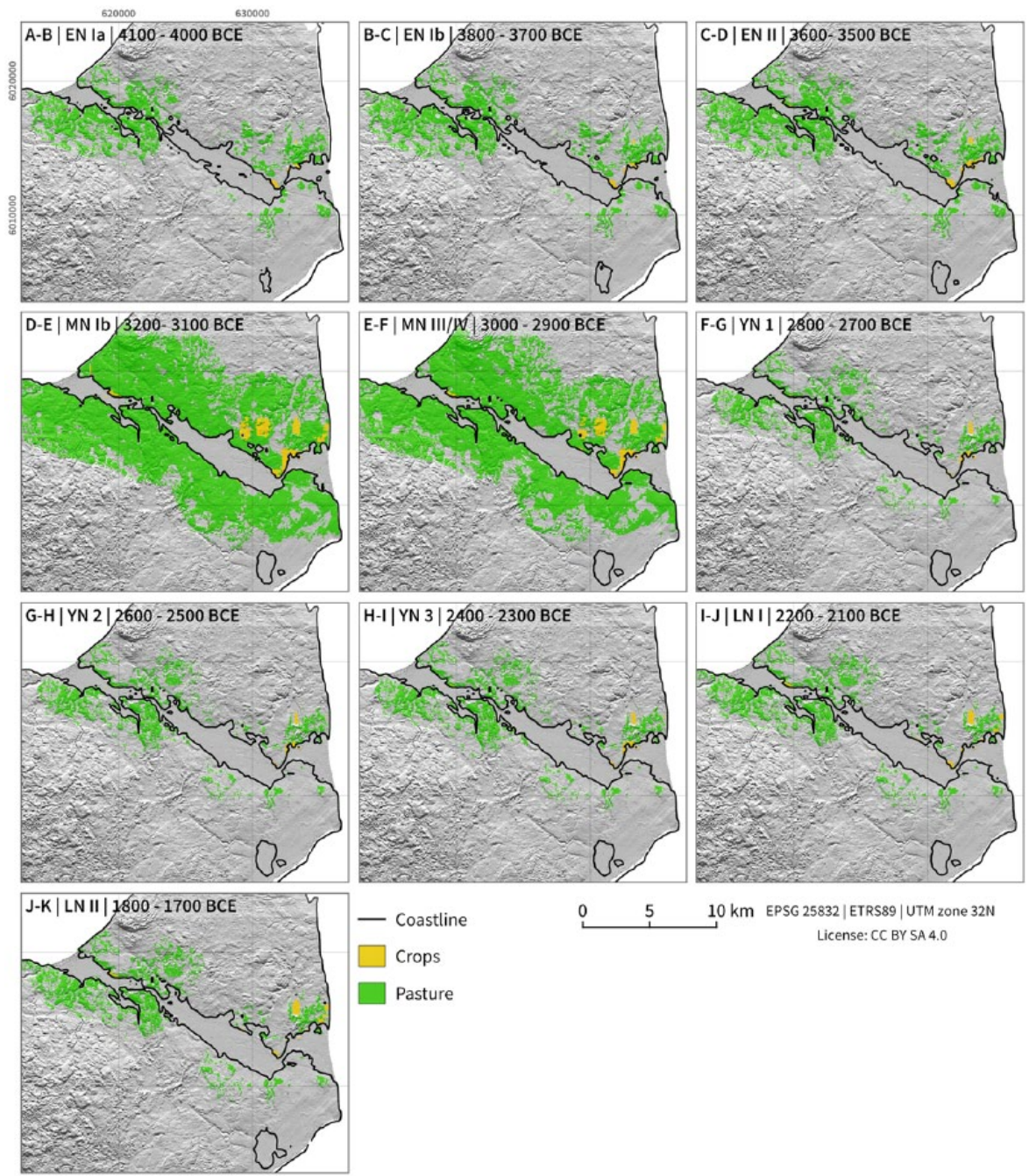

$10 \mathrm{~km}$ EPSG 25832 | ETRS89 | UTM Zone 32N

License: CC BY SA 4.0

Figure 6. Modeled areas of land-use practices. Because of the small areal demand of wood and arboriculture, these are not mapped. Shown are periods of cultural change and accompanied transformations (coastline is reconstructed as explained in Supplemental Material G available online; utilized number of settlements as outlined in Table I).

data, especially on the economic characteristics of the individual sites will help to produce more realistic, spatially explicit results. The phase (B) of Neolithization from 4100 BCE, whose phenomena were already apparent in the Mesolithic, from 5100 BCE onward through imports (Hartz et al., 2011), and the occurrence of domesticated pigs (Krause-Kyora, 2011) in the study area Oldenburger Graben, is deeply connected with the great environmental potential of the firth region. Here, various habitats are allocated side by side in a relatively small region. Thus, multiple resources are available from marine, lacustrine, and terrestrial environments. The occupation of the inland allowed small-scale intensive crop growing in the direct vicinity of the farmstead. Most probably, in particular, those marshy areas that underwent seasonal flooding were increasingly used for cattle pasture (Rickert, 2007). Marine resources, game, and wild plant food were used to a variable extent and declined during the course of the Early Neolithic I (Figure 5c). The increasing construction of megalithic graves in the distribution area of the Funnel Beaker groups, which can be observed supraregionally, and the simultaneous opening of the landscape from 3600 BCE (D-E) onward, indicates a population growth (Hinz et al., 2012), which requires a larger area for the cultivation of crops, pastures, and wood extraction. In addition, marine resources are increasingly used again. This is a period in which, analogously, increased domestic site activity and the development of villages such as Oldenburg-Dannau LA 77 (Brozio, 2016) lead to a greater diversity of the food resources utilized. At the beginning of the third millennium (3100 BCE in the pollen record), there is an overall decline in the areas required. This is a period in which strong sociocultural changes can be observed in the form of Store-Valby groups (Davidsen, 1978) and the emergence of Single Grave groups (Hübner, 2005). These phenomena are associated with a stronger differentiation into smaller group sizes and smaller domestic sites in the form of hamlets (Müller, 2012; Müller, 2013). The required areas are reduced to sizes reached between 4100 and $3600 \mathrm{BCE}$, during the phase of Neolithization and inland development (B-C). In contrast, from $2200 \mathrm{BCE}$, with the introduction of retouched flint objects (I-J), in particular, the flint sickles (Jensen, 1994; Kühn, 1979), an increase in the area for arable crops can be observed. This is also supported by pollen evidence and supra-regional participation in networks for the distribution of metal (Schultrich, 2014; Vandkilde et al., 2017) can be observed.

Since the model is sensitive to the input data as well as threshold selection, we refer to them only in terms of a relative comparison between the different phases and methods. From the empirical data, for example, there is a strong bias in the archaeobotanical data because oil plants and apples are underrepresented. This is because of different taphonomy and use in different contexts, if compared with cereals that are the main components in charred assemblages. Thus, the caloric calculations can only partly be supported by our empirical data, but follow the assumption that the cereal component delivers the main caloric input (emmer, barley, and some einkorn) and is added to a minor content from the Early Neolithic I onward by oil plants. For the estimation of the content of gathered plants, a wide variety of edible species is considered which exceeds 
the common gathered plants such as apple or hazel. Among the wild gathered plants, there are those with starch rich seeds such as the Polygonaceae, Chenopodiaceae, and some wild Poaceae. Other species deliver micro-nutrients or vitamin $\mathrm{C}$, like the berries in the genus Rubus (cf. Kirleis et al., 2012). These aspects could not yet be integrated into the model. With respect to land-use, the gathering of wild plants in the Neolithic took place at small-scale openings in the dense woodlands and at the woodland edge, where conditions for the growth of light-demanding species are suitable. While intentional woodland management of hazel was suggested already for Mesolithic times, for crab apple, careful management might be considered from the Neolithic time period onward, which may have required/consumed minor space in the vicinity of the farmstead and village (Kirleis, 2018; Klooß, 2015: 331). This shows that additional on-site studies with strong empirical background and sound material, and best from different archives providing multiple assemblages, are necessary for a further qualification of the resulting values from the land-use model. Further empirical data, especially on the economic characteristics of more individual sites will help to produce more realistic, spatially explicit results.

The population sizes extrapolated on the basis of the sizes of the excavated settlement sites provide particular uncertainties in the models presented. Within the Middle Funnel Beaker culture, the first settlements exhibited especially greater numbers of inhabitants, in contrast to the otherwise excavated individual farms which are known, and this has an effect on the overall calculation. Even if a certain contradiction seems to exist (the 'expansion' is not shown in the pollen analysis, but this can also be attributed to the reduction of the visible impacts because of the local population agglomerations), the peak is also confirmed by the ${ }^{14} \mathrm{C}$ curve sum calibration (Feeser et al., this issue; cf. Dörfler et al., 2012; Feeser et al., 2012, 2015). Discrepancies between pollen-analytically and archaeologically achieved data show the key issues where more data have to be collected, or different interpretations of data have to be developed. As the pollen record as an off-site record reflects the wider region, this may also play a role, especially when the utilized (available) sample of archaeological material is considered.

\section{Conclusion}

The results from the modeled quantitative reconstruction of landuse show that the Late Mesolithic and Neolithic transformation processes in general have only an insignificant effect on the size of areas that are effected by the land-use patterns in the research area. Nevertheless, changing patterns of land-use occur because of different subsistence technologies and social patterns to organize subsistence as both an economic and a social practice with impact on the environmental conditions.

In the Early Neolithic, the land area required for the gathering of wild plants declines. The by far largest areas in the Neolithic were required for domestic animal breeding, which in the model are named 'pastures' and which include areas for browsing in light forest and in the seasonally flooded marshland adjacent to the firth. Areas for crop growing show limited extension, while wood extraction has the least area requirement.

The most obvious transformation of land-use with respect to land requirement is that the proportion of required land increases with regional demographic growth in municipal forms of organization in villages up to 3000 BCE (D-E), and decreases again with the development of smaller groups in the MN V and the Younger Neolithic $(\mathrm{F} / \mathrm{F}-\mathrm{G})$. Although transformations are considered to have a significant influence on the forms of social organization and imply different social behavior (such as jointly created monumentality, organization of village communities, development of new ideologies like warrior ideology, and individualization or the formation of specialist for flint production), the land-use practices for subsistence farming in the long run remain on a continuous level with regard to the areas used. The socio-cultural changes therefore have only a minor impact on the land-use in relation to the subsistence economy. They are represented by the formation of a ritual cultural landscape structured most of all visible by monuments.

In principle, it can be concluded that the carrying capacity of the investigated regional landscape was not reached at any time. This insight indicates that the social organization of the economy and the cultural development of Neolithic societies are decisive for the social changes in the transformation phases. The results highlight the necessity to analyze other well researched areas in a similar way. Also for other Neolithic and Chalcolithic societies, analyses have shown that postulated environmental shortages related with subsistence economies were overestimated. Thresholds were hardly reached and the carrying capacity was never exceeded to such extent as it was originally postulated (cf. Tripolye, Ohlrau et al. 2016; Dal Corso et al., this issue).

\section{Acknowledgements}

The research was conducted and financed in context of the Collaborative Research Center 1266 'Scales of Transformation - Human-environmental interaction in prehistoric and archaic societies' of the German Research foundation (DFG, German Research Foundation - project number 2901391021 - SFB 1266). We want thank the two anonymous reviewers for their comments and remarks that helped to clarify and improve this paper.

\section{Funding}

The author(s) received no financial support for the research, authorship, and/or publication of this article.

\section{Supplemental material}

Supplemental material for this article is available online.

\section{Notes}

1. Phenomena such as the Globular Amphora or Bell Beaker types are part of other contemporary groups in the research area.

2. Periods and transformation phases only partly overlap with the traditional archaeological phases of the Neolithic as the ladder are in some instances the result of research traditions and not so much of a compilation of all archives, which are now available because of modern archaeological methods.

3. The discrepancies of the two approaches that occur for particular phases may go back to different bias in each record. For the pollen data set, the limitations lay certainly in the weak chronology because radiocarbon dates are missing and the correlation with neighboring archives to gain proper age-depths models is a real challenge. The fuzzy approach, because of its small input data and simplifying assumptions, is not able to offer as detailed information as the pollen data, what results in the omission of various shorter dynamics and changes. Also the archeological background data for Younger Neolithic (YN) and Late Neolithic (LN) domestic sites are extremely week.

\section{ORCID iDs}

Daniel Knitter iD https://orcid.org/0000-0003-3014-4497

Jan Piet Brozio (iD https://orcid.org/0000-0001-6437-0949

Ingo Feeser (D) https://orcid.org/0000-0002-9618-5139

Wolfgang Hamer iD https://orcid.org/0000-0002-5943-5020

Johannes Müller (iD https://orcid.org/0000-0002-3538-197X

\section{References}

Andersen SH (2000) Kökkenmöddinger' (shell middens) in Denmark: A survey. Proceedings of the Prehistoric Society 66: 361-384. 
Antolín F, Bleicher N, Brombacher C et al. (2016) Quantitative approximation to large-seeded wild fruit use in a Late Neolithic lake dwelling: New results from the case study of layer 13 of Parkhaus Opéra in Zürich (Central Switzerland). Quaternary International 404: 56-68.

Averdieck F-R (2004) Zur Vegetations-und Siedlungsgeschichte von Starigard/Oldenburg. Ein palynologischer Beitrag zur Wall-und Siedlungsgrabung. In: Haffner A and Müller-Wille M (eds) Starigard/Oldenburg, Hauptburg der Slawen in Wagrien, V Naturwissenschaftliche Beiträge (Offa-Bücher) 82. Hamburg: Wachholtz, pp. 95-127.

Barber KE, Chambers FM and Maddy D (2004) Late-Holocene climatic history of northern Germany and Denmark: Peat macrofossil investigations at Dosenmoor, Schleswig-Holstein, and Svanemose, Jutland. Boreas 33(2): 132-144.

Bogaard A, Fraser R, Heaton THE et al. (2013) Crop manuring and intensive land management by Europe's first farmers. Proceedings of the National Academy of Sciences of the United States of America 110(31): 12589-12594.

Böhner J and Selige T (2006) Spatial prediction of soil attributes using terrain analysis and climate regionalisation. In: Böhner J, McCloy KR and Strobl J (eds) SAGA - Analysis and Modelling Applications. Göttingen: Verlag Erich Goltze GmbH, pp. 13-27.

Böse M, Ehlers J and Lehmkuhl F (2018) Holozäne Klima- und Landschaftsgeschichte. In: Böse M, Ehlers J and Lehmkuhl F (eds) Deutschlands Norden: vom Erdaltertum zur Gegenwart. Berlin; Heidelberg: Springer, pp. 161-194.

Brozio JP (2016) Megalithanlagen und Siedlungsmuster im Trichterbecherzeitlichen Ostholstein. Frühe Monumentalität und soziale Differenzierung. Bonn: Dr. Rudolf Habelt GmbH.

Brozio JP (in press) Zur absoluten Chronologie der Einzelgrabkultur in Norddeutschland und Nordjütland. Germania.

Brozio JP, Demnick D, Dibbern H et al. (2012) Periodisierung der Trichterbecher-Gesellschaften: Ein Arbeitsentwurf. In: Hinz M and Muller J (eds) Siedlung, Grabenwerk, Großsteingrab Studien zu Gesellschaft, Wirtschaft und Umwelt der Trichterbechergruppen im nördlichen Mitteleuropa. Bonn: Dr. Rudolf Habelt GmbH, pp. 29-33.

Brozio JP, Dörfler W, Eriksen V et al. (2017) Transformations Dimensionen - Wildbeuter, Bodenbauer und frühe Metalurgen: Ein neues Großprojekt der Uni Kiel. Archäologische Nachrichten aus Schleswig-Holstein 22: 18-21.

Brozio JP, Dörfler W, Feeser I et al. (2014) A Middle Neolithic well from northern Germany: A precise source to reconstruct water supply management, subsistence economy, and deposition practices. Journal of Archaeological Science 51: 135-153.

Brozio JP, Filipovic D, Schmölcke U et al. (2018) Mittel- bis Jungneolithische Siedlungshinterlassenschaften zwischen 3300-2600 v. Chr. - Der Fundplatz Oldenburg LA 232 im Oldenburger Graben, Ostholstein. Prähistorische Zeitschrift 93: $185-224$.

Cornille A, Antolin F, Garcia E et al. (2019) A multifaceted view on apple tree domestication. Trends in Plant Science.

Czebreszuk J (1998) From Stone to Bronze: The Metalwork of the Late Neolithic and Earliest Bronze Age in Denmark. Jutland: Helle Vandkilde, Aarhus University Press.

Dal Corso M, Hamer W, Hofmann R et al. (this issue) Modelling landscape transformation at the Chalcolithic Tripolye megasite of Maidanetske (Ukraine): Wood demand and availability. The Holocene.

Davidsen K (1978) The Final TRB Culture in Denmark: A Settlement Study. Copenhagen: Akademisk Forlag.

Demicco RV (2004) Fuzzy logic and earth science: An overview. In: Demicco RV and Klir GJ (eds) Fuzzy Logic in Geology. Burlington, NJ: Academic Press, pp. 63-102.
Dibbern H (2015) Das trichterbecherzeitliche Westholstein: Eine Studie zur neolithischen Entwicklung von Landschaft und Gesellschaft. Kiel: Christian-Albrechts-University zu Kiel.

Diers S (2018) Mensch-Umweltbeziehungen zwischen 4000 und 2200 cal BC. In: Müller J (ed.) Frühe Monumentalität und soziale Differenzierung Bd. Bonn: Dr. Rudolf Habelt GmbH, pp. 1-225.

Dörfler W (2017) Von der Dichte des naturnahen Waldes und den „Flaschenhälsen" der Wildpopulationen. In: Lechterbeck J and Fischer E (eds) Kontrapunkte - Festschrift Manfred Rösch. Universitätsforschungen zur prähistorischen Archäologie 300. Bonn: Dr. Rudolf Habelt GmbH, pp. 95-113.

Dörfler W and Müller J (eds) (2008) Umwelt - Wirtschaft - Siedlungen im dritten vorchristlichen Jahrtausend Mitteleuropas und Südskandinaviens. Internationale Tagung Kiel 4.-6. November 2005. Neumünster: Offa-bücher, pp. 265-274.

Dörfler W, Feeser I, van den Bogaard C et al. (2012) A highquality annually laminated sequence from lake Belau, northern Germany: Revised chronology and its implications for palynological and tephrochronological studies. The Holocene 22(12): 1413-1426.

Dreibrodt S, Lubos C, Terhorst B et al. (2010) Historical soil erosion by water in Germany: Scales and archives, chronology, research perspectives. Quaternary International 222(1): $80-95$.

Effenberger H (2018) Pflanzennutzung und Ausbreitungswege von Innovationen im Pflanzenbau der Nordischen Bronzezeit und Angrenzender Regionen. Büttelborn: Wachholtz.

Ehrmann O, Biester H, Bogenrieder A et al. (2014) Fifteen years of the Forchtenberg experiment - Results and implications for the understanding of Neolithic land use. Vegetation History and Archaeobotany 23(1): 5-18.

Ellenberg H and Leuschner C (2010) Vegetation Mitteleuropas mit den Alpen: in Ökologischer, Dynamischer und Historischer Sicht. Stuttgart: UTB.

Feeser I and Dörfler W (2015) The Early Neolithic in pollen diagrams from eastern Schleswig-Holstein and western Mecklenburg - Evidence for a 1000 years cultural adaptive cycle? In: Kabacinski J, Hartz S, Raemaekers DCM et al (eds) The Dabki Site in Pomerania and the Neolithisation of the North European Lowlands (C. 5000-3000 Calbc). Rahden: Verlag Marie Leidorf, pp. 291-306.

Feeser I, Dörfler W, Averdieck F-R et al. (2012) New insight into regional and local land-use and vegetation patterns in eastern Schleswig-Holstein during the Neolithic. In: Hinz M and Müller J (eds) Siedlung, Grabenwerk, Großsteingrab. Studien zu Gesellschaft, Wirtschaft und Umwelt der Trichterbechergruppen im Nördlichen Mitteleuropa. Bonn: Dr. Rudolf Habelt GmbH, pp. 159-191.

Feeser I, Dörfler W, Kneisel J et al. (this issue) Human impact and population dynamics in the Neolithic and Bronze Age: multi-proxy evidence from north-western Central Europe. The Holocene.

Fernandes R, Grootes P, Nadeau M-J et al. (2015) Quantitative diet reconstruction of a Neolithic population using a Bayesian mixing model (FRUITS): The case study of Ostorf(Germany). American Journal of Physical Anthropology 158(2): 325-340.

Fernandes R, Millard AR, Brabec M et al. (2014) Food reconstruction using isotopic transferred signals (FRUITS): A Bayesian model for diet reconstruction. PLoS ONE 9(2): e87436.

Fernandes R, Rinne C, Grootes PM et al. (2012) Revisiting the chronology of northern German monumentality sites: Preliminary results. In: Hinz M and Müller J (eds) Siedung, Grabenwerk, Großsteingrab. Bonn: Dr. Rudolf Habelt GmbH, pp. 87-103.

Fischer A, Olsen J, Richards M et al. (2007) Coast-inland mobility and diet in the Danish Mesolithic and Neolithic: Evidence 
from stable isotope values of humans and dogs. Journal of Archaeological Science 34(12): 2125-2150.

Fränzle O (2004) Reliefentwicklung und Bodenbildung in Schleswig-Holstein. In: Winkler G, Dahlke C and Bork H-R (eds) Streifzug durch 6000 Jahre Landnutzungs- und Landschaftswandel in Schleswig-Holstein: Ein Exkursionsführer. Kiel: Institut für Weltwirtschaft, pp. 11-35.

Fritsch B, Furholt M, Hinz M et al. (2010) Dichtezentren und lokale Gruppierungen - Eine Karte zu den Großsteingräbern Mittel- und Nordeuropas. Journal of Neolithic Archaeology. Epub ahead of print 20 October. DOI: 10.12766/jna.2010.56.

Furholt M (2016) Corded ware and bell beakers - A practicebased perspective on local communities, transregional interaction and social heterogeneity in Late Neolithic Europe. In: Furholt M, Großmann R and Szmyt M (eds) Transitional Landscape? Human Development in Landscapes. Bonn: Dr. Rudolf Habelt GmbH, pp. 117-131.

Glykou A (2011) Neustadt LA 156 - Ein submariner Fundplatz des späten Mesolithikums und frühesten Neolithikums in Schleswig-Holstein.Untersuchungen zur Subsistenzstrategie der letzte Jäger, Sammler und Fischer an der norddeutschen Osteseeküste. Kiel: Christian-Albrechts-University to Kiel.

Goldhammer J, Frenzel P, Ewersen J et al. (2008) Untersuchungen zur Stratigraphie, Fundverteilung und zum Fundspektrum der mittleren Ertebøllekultur in Ostholstein: Die Nachgrabungen in Grube-Rosenhof aus den Jahren 2001 und 2002. Archäologische Informationen 30(2): 107-110.

Hage F (2016) Büdelsdorf/borgstedt: Eine Trichterbecherzeitliche Kleinregion. Bonn: Dr. Rudolf Habelt GmbH.

Hamer W and Knitter D (2018) Fuzzylandscapes - Fuzzy analyses with a focus on raster data. Zenodo. Epub ahead of print 30 November. DOI: 10.5281/zenodo.1747005.

Hartz S (1999) Die Steinartefakte des Endmesolithischen Fundplatzes Grube-rosenhof: Studien an Flintinventaren aus der Zeit der Neolithisierung in Schleswig-Holstein und Südskandinavien. Neumünster: Wachholtz.

Hartz S (2002) Wangels, Kr. Ostholstein. Siedlung der späten Mittel- und Jungsteinzeit, LA 505. Offa. Berichte und Mitteilungen zur Urgeschichte, Frühgeschichte und Mittelalterarchäologie 59-60: 286-291.

Hartz S, Kalis AJ, Klassen L et al. (2011) Neue Ausgrabungen zur Ertebøllekultur in Ostholstein und der Fund von vier stratifizierten durchlochten donauländischen Äxten. In: Hartz S, Kalis AJ and Klassen L (eds) Liber Amicorum: Vergangene Zeiten. Gedenkschrift für J. Hoika. Bonn: Dr. Rudolf Habelt GmbH, pp. 25-61.

Hartz S, Kooijmans L and Terberger T (2007) From fish and seal and cattle: New research into the process of Neolithisation in northern Germany. In: Whittle A and Cummings V (eds) Going Over: The Mesolithic-Neolithic Transition in NorthWest Europe. London: The British Academy, pp. 567-594.

Heyd V (2017) Kossinna's smile. Antiquity 91(356): 348-359.

Hinz M, Feeser I, Sjögren K-G et al. (2012) Demography and the intensity of cultural activities: An evaluation of Funnel Beaker societies (4200-2800 cal BC). Journal of Archaeological Science 39(10): 3331-3340.

Höfgen W (2014) Der Muschelhaufen von Quern-Neukirchen LA 28: spätneolithisches Siedlungs-und Subsistenzverhalten in Schleswig-Holstein. PhD Thesis, Christian-Albrecht-Universität zu Kiel.

Hoika J (1972) Ein Trichterbecher aus Westerohrstedt, Nordfriesland. Offa: Berichte und Mitteilungen zur Urgeschichte, Frühgeschichte und Mittelalterarchäologie 28: 27-46.

Hoika J (1986) Die Bedeutung des Oldenburger Grabens für Besiedlung und Verkehr im Neolithikum. Offa: Berichte und Mitteilungen zur Urgeschichte, Frühgeschichte und Mittelalterarchäologie 43: 185-208.
Hoika J (1987) Das Mittelneolithikum zur Zeit der Trichterbecherkultur in Nordostholstein. Untersuchungen zu Archäologie und Landschaftsgeschichte. Neumünster: Wachholtz.

Horn R, Fleige H and Peth S (2006) Soils and Landuse Management Systems in Schleswig-Holstein (Germany) - Guide of ISTRO Excursion. Kiel: Institut für Pflanzenernährung und Bodenkunde.

Hübner E (2005) Jungneolithische Gräber auf der Jütischen Halbinsel: Typologische und Chronologische Studien zur Einzelgrabkultur. Beilagen: Sortierte Gräber-typen-matrix der Korrespondenzanalyse mit dem Fundmaterial Dänemarks, Nord-und Zentraljütland, Zentral-und Südjütland, Schleswigholstein, Fundlisten. Køpenhaven: Det Kongelige Nordiske Oldskriftselskab.

Hughes RE, Weiberg E, Bonnier A et al. (2018) Quantifying land use in past societies from cultural practice and archaeological data. Land 7(1): 9.

Jakobsen O (2004) Die Grube-Wesseker Niederung (Oldenburger Graben, Ostholstein): Quartärgeologische und geoarchäologische Untersuchungen zur Landschaftsgeschichte vor dem Hintergrund des anhaltenden postglazialen Meeresspiegelanstiegs. $\mathrm{PhD}$ Thesis, Christian-Albrechts-University to Kiel.

Jasiewicz J (2011) A new GRASS GIS fuzzy inference system for massive data analysis. Computers \& Geosciences 37(9): $1525-1531$.

Jasiewicz J and Hildebrandt-Radke I (2009) Using multivariate statistics and fuzzy logic system to analyse settlement preferences in lowland areas of the temperate zone: An example from the Polish Lowlands. Journal of Archaeological Science 36(10): 2096-2107.

Jensen HJ (1994) Flint Tools and Plant Working: Hidden Traces of Stone Age Technology - A Use Wear Study of Some Danish Mesolithic and TRB Implements. Aarhus: Aarhus University.

Johnson I (2004) Aoristic analysis: Seeds of a new approach to mapping archaeological distributions through time. In: Fischer-Ausserer K, Börner W and Goriany M (eds) Enter the Past: The E-Way into the Four Dimensions of Cultural Heritage - CAA 2003: Computer Applications and Quantitative Methods in Archaeology (BAR International Series 1227). Tübingen: Universitätsbibliothek Tübingen, pp. 448-452. Available at: http://dx.doi.org/10.15496/publikation-2085.

Kalis AJ and Meurers-Balke J (1998) Die 'Landnam'-Modelle von Iversen und Troels-Smith zur Neolithisierung des westlichen Ostseegebietes - Ein Versuch ihrer Aktualisierung. Prähistorische Zeitschrift 73(1): 1-24.

Karnatz J (1987) Die Vorgeschichte des Kreises Ostholstein, der Südteil des Altkreises Oldenburg, die Stein-und Bronzezeit. Kiel: Christian-Albrechts-University to Kiel.

Kirleis W (2018) The cultural significance of plants. In: Haug A, Käppel L and Müller J (eds) Past Landscapes: The Dynamics of Interaction between Society, Landscape, and Culture. Leiden: Sidestone Press, pp. 169-182.

Kirleis W and Fischer E (2014) Neolithic cultivation of tetraploid free threshing wheat in Denmark and Northern Germany: Implications for crop diversity and societal dynamics of the Funnel Beaker Culture. Vegetation History and Archaeobotany 23(S1): 81-96.

Kirleis W, Klooß S, Kroll H et al. (2012) Crop growing and gathering in the northern German Neolithic: A review supplemented by new results. Vegetation History and Archaeobotany 21(3): 221-242.

Klassen L (2001) Frühes Kupfer im Norden. Aarhus: Aarhus University Press.

Klassen L (2004) Jade und Kupfer: Untersuchungen zum Neolithisierungsprozess im Westlichen Ostseeraum unter besonderer Berücksichtigung der Kulturentwicklung Europas 
5500-3500 BC. Århus: Jutland Archaeological Society, Moesgård Museum.

Klir G and Yuan B (1995) Fuzzy Sets and Fuzzy Logic. Upper Saddle River, NJ: Prentice Hall.

Klooß R (2008) Ein Fundplatz des Übergangs vom Mittelneolithikum A zum Mittelneolithikum B aus Wangels LA 505, Kreis Ostholstein: Ein Vorbericht. In: Dorfler W and Muller J (eds) Umwelt - Wirtschaft - Siedlungen im dritten vorchristlichen Jahrtausend Mitteleuropas und Südskandinaviens. Internationale Tagung Kiel 4.646. Neumünster: Wachholtz, pp. 127-134.

Klooß S (2015) Mit Einbaum und Paddel zum Fischfang: Holzartefakte von Endmesolithischen und Frühneolithischen Küstensiedlungen an der Südwestlichen Ostseeküste. Kiel; Hamburg: Wachholtz.

Knitter D, Hamer W, Günther G et al. (2018) LandUseQuantifieR. Zenodo. Epub ahead of print 29 November. DOI: 10.5281/ zenodo. 1709568.

Krause-Kyora B (2011) Molekulargenetische und archäologische Untersuchungen zur Domestikation und Züchtung des Schweins (Sus scrofa). PhD Thesis, Christian-Albrechts-University to Kiel.

Krossa VR, Moros M, Leduc G et al. (2017) Regional climate change and the onset of farming in northern Germany and southern Scandinavia. The Holocene 27(10): 1589-1599.

Kühn HJ (1979) Das Spätneolithikum in Schleswig-Holstein. Neumünster: Wachholtz.

Loots L, Nackaerts K and Waelkens M (1999) Fuzzy viewshed analysis of the Hellenistic city defence system at Sagalassos, Turkey. In: Dingwall LS, Exon V, Gaffney S et al. (eds) Archaeology in the Age of the Internet. CAA97. Computer Applications and Quantitative Methods in Archaeology. Proceedings of the 25th Anniversary Conference, University of Birmingham, April 1997 (BAR International Series 750). Oxford: Archaeo Press, p. 82.

Lüning J and Meurers-Balke J (1980) Experimenteller Getreideanbau im Hambacher Forst, Gemeinde Elsdorf, Kreis Bergheim/Rheinland. Bonner Jahrbücher 180: 305-344.

Marchetti C (1994) Anthropological invariants in travel behavior. Technological Forecasting and Social Change 47(1): 75-88.

Marquer L, Gaillard M-J, Sugita S et al. (2014) Holocene changes in vegetation composition in northern Europe: Why quantitative pollen-based vegetation reconstructions matter. Quaternary Science Reviews 90: 199-216.

Mennenga M (2016) Archäoprognose in Schleswig-Holstein. In Müller J (ed.) Wasser, Landschaft und Gesellschaft: Studien zum Ressourcenmanagement der Trichterbechergesellschaft. Bonn: Dr. Rudolf Habelt GmbH, pp. 117-245.

Mertens K (2003) Einflüsse der Glockenbecherkultur in Norddeutschland. In: Czebreszuk J and Szmyt M (eds) The Northeast Frontier of Bell Beakers: Proceedings of the Symposium Held at the Adam Mickiewicz University, Poznan (Poland), May 26-29 2002. Oxford: Archaeo Press, pp. 51-71.

Meurers-Balke J (1983) Siggeneben-Süd: Ein Fundplatz der Frühen Trichterbecherkultur an der Holsteinischen Ostseeküste (Müller-Wille, M. and Struve, K. W.offa-bücher 50). Neumünster: Wachholtz.

Meurers-Balke J (1997) Pollenanalytische Untersuchungen in Wangels LA 505. In: Reichstein J (ed.) Ostholstein vor 5000 Jahren: Archäologische Forschungen zur Jungsteinzeit in der westlichen Grube-Wessek-Niederung Kreis Ostholstein, Gemeinde Wangels. Schleswig: Selbstverl, pp. 13-14.

Meynen E and Schmithüsen (1962) Handbuch der Naturräumlichen Gliederung Deutschlands: 1953-1962. Bad Godesberg: Bundesanst. für Landeskunde u. Raumforschung.

Mischka D (2004) Aoristische Analyse in der Archäologie. Archäologische Informationen 27(2): 233-243.
Mischka D, Dörfler W, Grootes P et al. (2006) Die Neolithische Feuchtbodensiedlung Bad Oldesloe-Wolkenwehe LA 154. Vorbericht zu den Untersuchungen 59-60: 25-64.

Mrotzek A, Couwenberg J, Theuerkauf M et al. (2017) MARCO POLO - A new and simple tool for pollen-based stand-scale vegetation reconstruction. The Holocene 27(3): 321-330.

Müller J (1998) Zur chronologischen Datierung der europäischen Megalithik. In: Fritsch B, Maute M, Matuschik I et al. (eds) Tradition und Innovation. Rahden: De Gruyter, pp. 63-105.

Müller J (2011) Megaliths and Funnel Beakers: Societies in Change 4100-2700 BC. Amsterdam: Kroon-Vordaacht.

Müller J (2012) Mesolithisch - neolithisch: Zur Entwicklung von Hütten und Häusern im südlichen Skandinavien und nördlichen Mitteleuropa. Offa: Berichte und Mitteilungen zur Urgeschichte, Frühgeschichte und Mittelalterarchäologie 69-70: 249-264.

Müller J (2013) Vom Muschelhaufen zum Langhügel: Ertebølle und Trichterbecher - Landschaften als divergierende Raumkonzepte. In: Hansen S and Meyer M (eds) Parallele Raumkonzepte. Berlin; Boston, MA: De Gruyter, pp. 133-153.

Müller J (2014) 4100-2700 B.C.: Monuments and ideologies in the neolithic landscape. In: Osborne JF (ed.) Approaching Monumentality in Archaeology. Albany, NY: State University of New York Press, pp. 181-217.

Müller J and Peterson R (2015) Ceramics and society in northern Europe. In: Fowler C, Harding J and Hofmann D (eds) The Oxford Handbook of Neolithic Europe. Oxford: Oxford University Press, pp. 573-604.

Müller J, Dibbern H and Hage F (2014) Non-megalithic mounds beneath megaliths: A new perspective on monumentality in north central Europe. In: Furholt M (ed.) Landscapes, Histories and Societies in the Northern European Neolithic. Bonn: Dr. Rudolf Habelt GmbH, pp. 171-182.

Nakoinz O (2012) Datierungskodierung und chronologische Inferenz - Techniken zum Umgang mit unscharfen chronologischen Informationen. Praehistorische Zeitschrift 87(1): 187-207.

Nelle O and Dörfler W (2008) A summary of the late-and postglacial vegetation history of Schleswig-Holstein. In: Dengler J, Dolnik C and Trepel M (eds) Flora, Vegetation, and Nature Conservation from Schleswig-Holstein to South America Festschrift for Klaus Dierßen on Occasion of his 60th Birthday. Kiel: Mitteilungen der Arbeitsgemeinschaft Geobotanik in Schleswig-Holstein und Hamburg, pp. 45-68.

Ohlrau R, Dal Corso M, Kirleis W et al. (2016) Living on the edge? Carrying capacities of trypillian settlements in the BuhDnipro interfluve. In: Müller J, Rassmann K and Vydeiko M (eds) Trypillia Mega-Sites and European Prehistory. 41003400 BCE. London: Routledge, pp. 207-220.

Oreskes N, Shrader-Frechette K and Belitz K (1994) Verification, validation, and confirmation of numerical models in the earth sciences. Science 263(5147): 641-646.

Pebesma EJ (2004) Multivariable geostatistics in S: The Gstat package. Computers \& Geosciences 30(7): 683-691.

Pedersen L (1997) They put fences in the sea. In: Pedersen L, Fischer A and Aaby B (eds) The Danish Storebaelt Since the Ice Age - Man, Sea and Forest. Copenhagen: Storebaelt, pp. 124-143.

Popa CN and Knitter D (2015) From environment to landscape: Reconstructing environment perception using numerical data. Journal of Archaeological Method and Theory 23(4): 1285-1306.

Ratcliffe JH (2000) Aoristic analysis: The spatial interpretation of unspecific temporal events. International Journal of Geographical Information Science 14(7): 669-679.

Ratcliffe JH and McCullagh MJ (1998) Aoristic crime analysis. International Journal of Geographical Information Science 12(7): 751-764. 
Rickert BH (2007) Vegetationskundliche Interpretation botanischer Makroreste aus den ertebøllezeitlichen und frühneolithischen Fundschichten des Siedlungsplatzes Wangels LA 505. Schriften des Naturwissenschaftlichen Vereins für Schleswig-Holstein 69: 15-28.

Sørensen M, Lübcke H and Gross D (2018) The Early Mesolithic in Southern Scandinavia and Northern Germany. In: Milner N, Conneller C and Taylor B (eds) Star Carr. York: White Rose University Press, pp. 305-329.

Schibler J (2008) Wirtschaftliche Bedeutung der Viehzucht während des 3. Jts. v. Chr. aufgrund der Tierknochenfunde der Fundstellen im Schweizerischen Alpenvorland. In: Dörfler W and Müller J (eds) Umwelt - Wirtschaft - Siedlungen im Dritten Vorchristlichen Jahrtausend Mitteleuropas und Südskandinaviens. Neumünster: Wachholtz, pp. 339-379.

Schibler J, Hülser-Plogmann H, Jacomet S et al. (1997) Ökonomie und Ökologie Neolithischer und Bronzezeitlicher Ufersiedlung am Zürichsee (Ergebnisse der Ausgrabungen Mozartstrasse, Kanalisationssanierung Seefeld, Akad/pressehaus und Mythenschloss in Zürich. Band B: Datenkatalog (Tabellen D 62-360)). Zürich: Kommunikation.

Schultrich S (2014) Metall- und Silexdeponierungen im Spätneolithikum Schleswig-Holsteins: Verbreitungsmuster und soziale Bedeutung. PhD Thesis, Christian-Albrechts-Universität zu Kiel.

Schultrich S (2018) Das Jungneolithikum in Schleswig-Holstein. Master's Thesis, Christian-Albrechts-Universität zu Kiel.

Schwarck N (2018) Spätneolithische Flintdolche in Ostholstein. Master's Thesis, Christian-Albrechts-Universität zu Kiel.

Sjögren K-G (2017) Modeling middle Neolithic Funnel Beaker diet on Falbygden, Sweden. Journal of Archaeological Science: Reports 12: 295-306.

Sørensen HH (1998) Spodsbjerg: En yngre stenalders boplads på Langeland $=$ A younger Stone Age settlement on Langeland. Rudkøbing: Langelands Museum.

Souci SW, Fachmann W and Kraut H (2016) Die Zusammensetzung der Lebensmittel, Nährwert-Tabellen. Stuttgart: Wissenschaftliche Verlagsgesellschaft.

Steffens J (2007) Die Bedeutung der Jagd in der Trichterbecherkultur. Archäologisches Korrespondenzblatt 37(4): 471-487.

Struve KW (1955) Die Einzelgrabkultur in Schleswig-Holstein: und ihre Kontinentalen Beziehungen. Neumünster: Wachholtz.

Sugita S (1998) Modelling pollen representation of vegetation. In: Gaillard M-J and Berglund BE (eds) Quantification of Land
Surfaces Cleared of Forests during the Holocene - Modern Pollen/Vegetation/Landscape Relationships as an Aid to the Interpretation of Fossil Pollen Data. Stuttgart: Gustav Fischer, pp. 1-16.

Sugita S (2007a) Theory of quantitative reconstruction of vegetation I: Pollen from large sites REVEALS regional vegetation composition. The Holocene 17(2): 229-241.

Sugita S (2007b) Theory of quantitative reconstruction of vegetation II: All you need is LOVE. The Holocene 17(2): 243-257.

Sugita S, Gaillard M-J and Broström A (1999) Landscape openness and pollen records: A simulation approach. The Holocene 9(4): 409-421.

Terberger T, Burger J, Lüth F et al. (2018) Step by step - The Neolithisation of northern central Europe in the light of stable isotope analyses. Journal of Archaeological Science 99: 66-86.

Theuerkauf M and Couwenberg J (2017) The extended downscaling approach: A new R-tool for pollen-based reconstruction of vegetation patterns. The Holocene 27(8): 1252-1258.

Theuerkauf M, Couwenberg J, Kuparinen A et al. (2016) A matter of dispersal: REVEALSinR introduces state-of-the-art dispersal models to quantitative vegetation reconstruction. Vegetation History and Archaeobotany 25(6): 541-553.

Trondman A-K, Gaillard M-J, Mazier F et al. (2015) Pollenbased quantitative reconstructions of Holocene regional vegetation cover (plant-functional types and land-cover types) in Europe suitable for climate modelling. Global Change Biology 21(2): 676-697.

Vandkilde H (1996) From Stone to Bronze: The Metalwork of the Late Neolithic and Earliest Bronze Age in Denmark. Aarhus: Jutland Archaeological Society Moesgard.

Vandkilde H, Northover JP, Becker K et al. (2017) The Metal Hoard from Pile in Scania, Sweden: Place, Things, Time, Metals, and Worlds around 2000 BCE. Aarhus: Aarhus University Press; Swedish History Museum.

Venus J (2004) Pollenanalytische Untersuchungen zur Vegetations-und Siedlungsgeschichte Ostwagriens und der Insel Fehmarn. In: Haffner A and Müller-Wille M (eds) Starigard/ oldenburg, Hauptburg Der Slawen in Wagrien, V Naturwissenschaftliche Beiträge. Haffner, A. and Müller-wille, M.offabücher. Neumünster: Wachholtz, pp. 31-94.

Warden L, Moros M, Neumann T et al. (2017) Climate induced human demographic and cultural change in northern Europe during the mid-Holocene. Scientific Reports 7(1): 15251.

Zadeh LA (1965) Fuzzy sets. Information and Control 8(3): $338-353$ 